\title{
PRIV ATE FILLS IN NAVIGABLE WATERS: A COMMON LAW APPROACH
}

Public riglts in navigable waters date from Roman times. ${ }^{1}$ They were consistently recognized in England as a restraint on the sovereign's otherwise absolute ownership and control of the waters of the sea and tidelands. ${ }^{2}$ This common law doctrine quickly became accepted in the United States, ${ }^{3}$ and all states recognize the public interests of cominerce, navigation, and fishery in the navigable waters of the state. ${ }^{4}$ However, the states, with the consent or abdication of the federal government, ${ }^{5}$ have freely granted away land beneath navigable waters to

1. See Note, The Public Trust in Tidal Areas, 79 YALE L.J. 762, 763-64 (1970) and sources cited therein. The Note describes generally the evolution of public rights in tidelands from early Roman laws to contemporary American doctrine.

2. R. Hall, An Essay on the Rights of the Crown and the Privileges of THE SUBJECT IN THE SEA-SHORES OF THE REALM 45-47 (1830).

3. See Weber v. Board of Harbor Comm'rs, 85 U.S. (18 Wall.) $57,65-66$ (1873); Pollard's Lessee v. Hagan, 44 U.S. (3 How.) 212, 229 (1845); Martin v. Waddell, 41 U.S. (16 Pet.) 366, 410 (1842). These cases dealt with disputes over tidelands. Barney v. Keokuk, 94 U.S. 324, 338 (1876), extended the common law rule to all waters navigable in fact. The most extensive judicial discussions of the cominon law public rights are in Illinois Cent. R.R. v. Illinois, 146 U.S. 387, 452-55 (1892), and Shively v. Bowlby, 152 U.S. 1, 11-48 (1894). See also Ward v. Mulford, 32 Cal. 365, $372-73$ (1867).

4. Stone, Public Rights in Water Uses and Private Rights in Land Adjacent to Water, in 1 WATERS AND Water Rights 177, 196-98 (R. Clark ed. 1967). Cf. Illinois Cent. R.R. v. Illinois, 146 U.S. 387, $452-54$ (1892).

5. It has never been doubted that the federal governinent unay exercise its paramount control over navigable waters of the United States. Martin v. Waddell, 41 U.S. (16 Pet.) 367, 410 (1842). See also Pollard's Lessee v. Hagan, 44 U.S. (3 How.) 212,229 (1845). But the precise source and reach of the federal control were articulated slowly. In Gibbons v. Ogden, 22 U.S. (9 Wheat.) 1 (1824), the Supreme Court defined the federal commerce power exercised under the commerce clause as comprehending "navigation, within the limits of every state in the Union; so far as that navigation may be, in any manner, connected with 'coinmerce with foreign nations, or among the several states, or with the Indian tribes." Id. at 197. In The Daniel Ball, 77 U.S. (10 Wall.) 557 (1870), the Court defined the waters over which this power extended as follows:

Those rivers must be regarded as public navigable rivers in law which are navigable in fact. And they are navigable in fact wheu they are used, or are susceptible of being used, in their ordinary condition, as highways for commerce, over which trade and travel are or nuay be conducted in the customary modes of trade and travel on water. And they constitute navigable waters of the United States within the meaning of the acts of Congress, in contradistinction from the navigable waters of the States, when they form in their ordinary condition by themselves, or by uniting with other waters, a continued highway over which commerce is or may be carried on with other States or foreign countries in the customary modes in which such commerce is conducted by water.

Id. at 563. For modern elaborations on this standard see note 32 infra. 
private persons to fill and otherwise commercially develop, ${ }^{8}$ requiring only that the developer keep the navigable channels clear for commerce.

Recent public concern for the environment and demand for expanded recreational opportunities have brought these doctrines into new prominence. ${ }^{7}$ One of the most dramatic and far-reaching responses to the conflict between public and private interests involved two private landowners on Lake Chelan in Washington. In Wilbour v. Gallagher ${ }^{8}$ the Supreme Court of Washington held that a private landfill in a navi-

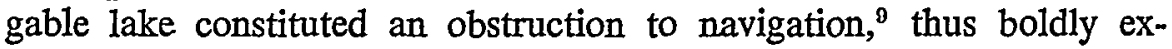
panding judicial supervision over such actions. Although the specific facts of this case are unlikely to recur, ${ }^{10}$ the simplicity of the judicial response suggests an enormous range of application. If the doctrinal foundation for the Wilbour decision is accepted by other courts, its logic

Only in 1888 did the Supreme Court declare that no federal common law existed concerning obstructions to navigation and that the paramount federal control must be embodied in specific statutes. Willamette Iron Bridge Co. v. Hatch, 125 U.S. 1, 8, 12-13 (1888). As a result, broad legislation was enacted specifically prohibiting unauthorized filhing of navigable waters. Rivers and Harbors Appropriation Aet of 1899, 33 U.S.C. $\$ \S 401-13$ (1970). The predecessor to this act had been given a broad construction [see United States v. Rio Grande Irrigation Co., 174 U.S. 690, 707-09 (1899)], but despite this interpretation federal regulation has been restricted to preservation of the navigable channels of navigable waters. See, e.g., United States v. Republic Steel Corp., 362 U.S. 482 (1960); Wisconsin v. Illinois, 278 U.S. 367 (1929); Sanitary Dist. v. United States, 266 U.S. 405 (1925). But cf. United States v. Appalachian Power Co., 311 U.S. 377, 423-27 (1940). Moreover, courts have been reluctant to interfere even with unauthorized fills. See, e.g., Great Northern Ry. v. Washington Elec. Co., 197 Wash. 627, 86 P.2d 208 (1939). Recent deeisions indicate, however, that a trend away from the restricted federal role is developing under the influence of new legislation dealing with preservation of the environment. See Zabel v. Tabb, 430 F.2d 199 (5th Cir. 1970), cert. denied, 401 U.S. 910 (1971) (fill permit denied, based on damage to wildlife without any showing of interference with navigation); cf. Citizens Comm. for the Hudson Valley v. Volpe, 302 F. Supp. 1083 (S.D.N.Y. 1969), aff'd, 425 F.2d 97 (2d Cir. 1970).

6. For example, in San Francisco Bay, 240 square miles of salt marshes have been filled and reclaimed, and 17 square miles of tide and submerged lands have been filled, reducing the land affected by tidal action from 692 to 435 square miles. M. ScotT, The Future of SAN Francisco Bay 24 (1963). To bring these and similar activities under general regulation and control, the California Legislature recently created the San Francisco Bay Conservation and Development Commission [CaL. Gov'T CODE $\$ \S 66600-61$ (West Supp. 1971)], which has the power to review requests for filling the bay. CAL. Gov'T CODE $\$ 66632$ (West Supp. 1971).

7. See, e.g., Sax, The Public Trust Doctrine in Natural Resource Law, $68 \mathrm{MrCH}$. L. REv. 471 (1970); Coinnent, San Francisco Bay: Regional Regulation for its Protection and Development, 55 CALIF. L. REv. 728, $769-79$ (1967); Note, The Public Trust in Tidal Areas, 79 Yale L.J. 762 (1970). Cf. Note, Public Access to Beaches, 22 Stan. L. Rev. 564 (1970).

8. 77 Wash. 2d 306, 462 P.2d 232 (1969), cert. denied, 400 U.S. 878 (1970).

9. Id. at $313,316,462 \mathrm{P} .2 \mathrm{~d}$ at $237,239$.

10. The water level of the lake had been artificially raised and fluctuated annually. Id. at 309,462 P.2d at 234 . Apparently the property involved had never been in state ownership. Id. at 307, 462, P.2d at 233. See note 12 infra. 
is potentially applicable to all property covered by navigable waterslakes, rivers, bays, and oceans. In particular, the decision could be the basis for a court-ordered moratorium on developments that require filling in tideland areas-perliaps the inost sensitive area of public concern at present-until the legislatures of the various states can respond with positive plans to preserve public rights in the face of massive pressures for development. ${ }^{11}$

However, the facts in Wilbour were unusual, for there was no state regulation or sale of the land in question. ${ }^{12}$ Part I of this Comment examines the Wilbour decision in detail and analyzes its doctrinal foundation, in order to understand and answer the question whether a fill constitutes an improper invasion of the public rights absent state action on behalf of the landowner.

Where the state lias regulated or sold the land, a court must determine whether the state action has coinpromised or terminated navigation rights so that the fill is not subject to judicial control. The ultimate potential of Wilbour depends upon this determmation, and a detailed investigation into the history and theory of state action concerning navigable waters is necessary for the answer. Part II undertakes this investigation by focusing on the experience of California, whicls within 120 years has seen several major changes in popular and judicial attitude towards its widely varied navigable waters. The wide range of state responses to California's navigable waters permits a detailed analysis of the difficulties and limitations of any attempt to apply the Wilbour doctrine widely. Legislative as well as judicial responses are considered in both parts of the Comment, since both entities can exercise influence in this area, and the actions of the one inevitably affect the responses of the other.

I

\section{Public Rights in Navigable Waters}

The land involved in Wilbour $v$. Gallagher is on the shore of Lake Clielan in Washington, a navigable lake. ${ }^{13}$ Prior to 1927 it was a

11. See notes 211-12 infra and accompanying text.

12. 77 Wash. $2 \mathrm{~d}$ at $307,316 \mathrm{n} .13,462 \mathrm{P} .2 \mathrm{~d}$ at $233,239 \mathrm{n} .13$. It is not clear from the opmion if the state originally sold the property, but in any event, it did not do so when the property was below the high-water line of navigable water. These circumstances are unique because the state acquires title to the land beneath its navigable waters upon admission to the Union. Weber v. Board of Harbor Comm'rs, 85 U.S. (18 Wall.) 57, 65-66 (1873). Here the property was probably sold to the original private owner by the federal government; only with the construction of the dam did it become land beneath navigable water.

13. 77 Wash. $2 \mathrm{~d}$ at $307,462 \mathrm{P} .2 \mathrm{~d}$ at 233 . It is 55 miles long and varies in width from one to two miles. 
natural body of water, ${ }^{14}$ but in that year the Chelan Electric Company obtained a permit to build a dam that would raise the level of the water by 21 feet for three months of the year. ${ }^{15}$ The defendants purchased land from the power coinpany, subject to the retained right to flood the land seasonally, ${ }^{16}$ and during the months of high water their property was subinerged.17 In 1961 the Gallaghers sought to establish a trailer court, and began filling their property and adjacent streets and alleys in order to raise their level five feet above high water. They claimed that their land, lying above the natural high-water level, was not subject to any public navigation rights, and they could use it as they pleased. Plaintiffs owned property adjacent to the Gallaghers that bordered on the lake only at high water. They brought a class action on behalf of themselves and the public asking that the fills be removed and that they be awarded damages for the loss of value to their properties. ${ }^{18}$

The trial court awarded damages on the ground that the fills violated both a public prescriptive right ${ }^{19}$ and public access guarantees over vacated streets and alleys, ${ }^{20}$ but it concluded that plaintiffs were estopped from requiring defendants to remove them. ${ }^{21}$ However, the supreme court rejected these tlieories, holding that the fills "constitute[d] an obstruction to navigation, ${ }^{, 22}$ and ordered them removed. ${ }^{23}$

14. Id.

15. Id. at 309,462 P.2d at 234 . The permit was obtained from the Federal Power Commission.

16. Id. at 314 n.11, 462 P.2d at 237 n.11. The nature of this right was not discussed by the court, and presumably even if treated as a covenant running with the land, it could only be enforced by the power company. Its importance lies in its presence in the deeds under which the Gallaghers took the property, putting them on notice that there were rights in others concerning the periodic flooding of their property.

17. Id. at 311,462 P.2d at 236.

18. Id. at 309-12, 462 P.2d at 235-37.

19. The prescriptive public right was allegedly gained over the 35 years the land had been periodically flooded:

[T] he general public have used the waters covering the [defendant's property]

for fishing, boating, swimming and for general recreational use and .... said use was open adverse, notorious and uninterrupted for said period, during the period of each year when water covers the [property].

Id. at 312,462 P.2d at 236 (quoting from the trial court). Damages were awarded plaintiffs for loss of property value due to the fills, which had obstructed plaintiffs' view, interfered with their use of the water, and created a problem of "unsightly" algae. Id., $462 \mathrm{P} .2 \mathrm{~d}$ at $236-37$.

20. Id. at 313,462 P.2d at 237 . See note 112 infra.

21. Id. at 312,462 P.2d at 236 . Estoppel was based on the presence of other fills in the area that had not been opposed. Id. at $316 \mathrm{n} .13,462$ P.2d at 239 n.13.

22. Id. at 313,462 P.2d at 237 .

23. Id. at $316,462 \mathrm{P} .2 \mathrm{~d}$ at 239 . The court ordered a retrial of the damages, concluding the award was excessive and based partially on a nonexistent prescriptive right of view. Id. at $317-18,462 \mathrm{P} .2 \mathrm{~d}$ at $239-40$.

The dissenters agreed with the majority's view of the prescriptive right: First, they argued that the public use is not a hostile claim. Id. at 319-20, 462 P.2d at 241 . 
The court considered public and private rights in a lybrid situation involving both the law of artificial navigable water and that of fluctuating navigable water, and the decision was not unanimous. However, the dispute between the majority and minority was confined to whether public navigation rights can ever exist beyond the natural high-water line. ${ }^{24}$ Both sides in Wilbour assumed that the public had navigation rights in the streets and alleys that were filled, that these navigation rights required those fills to be abated, and that these rights included recreational rights. ${ }^{25}$ However, these assumptions raise some serious questions, and ultimately Wilbour's influence may be seriously impaired by the court's failure to articulate their basis.

To reconstruct what the court assumed, it is first necessary to outline briefly the history of public navigation rights in the United States.

\section{A. Public Rights Generally}

According to Englisl cominon law, the King owned all rights to the sea up to the mean high-tide line, subject to the public right to use the tidelands for fishing and navigation. ${ }^{26}$ In the United States, the individual states were held to have gained title to the lands under navigable waters by virtue of their sovereignty ${ }^{27}$ and were required to

In view of the position taken below [see notes 101-09 infra and accompanying text] that the owner of land under navigable water may not prevent public use of the water regardless of its source [see Bohn v. Albertson, 107 Cal. App. 2d 738, 238 P.2d 128 (1st Dist. 1951)], the public use is indeed compatible with his title. Second, Washington has a presumption of permissive use by the public of unenclosed lands. Watson v. County Comm'rs, 38 Wash. 662, 80 P. 201 (1905). The presumption arises because such use does not ordimarily give notice to the owner of the land of an adverse claim. 77 Wash. 2d at 320, 462 P.2d at 241. Since there was no evidence that the public use of the water over Gallagher's land was other than permissive, this presumption precludes any holding of public prescriptive rights. Id.

The presumption of permissive use of unenclosed land has counterparts in other jurisdictions. See, e.g., F.A. Hihn Co. v. City of Santa Cruz, 170 Cal. 436, 150 P. 62 (1916). But see Gion v. City of Santa Cruz, 2 Cal. 3d 29, 41, 465 P.2d 50, 57, 84 Cal. Rptr. 162, 169 (1970); O'Banion v. Borba, 32 Cal. 2d 145, 195 P.2d 10 (1948). California does not allow the public to gain easements by prescription. People v. Sayig, 101 Cal. App. 2d 890, 896, 226 P.2d 702, 706 (1st Dist. 1951). For agreement that prescription has no place here, from a commentator generally enthusiastic about the result in Wilbour v. Gallagher, see Corker, Thou Shalt Not Fill Public Waters Without Public Permission, 45 Wash. L. REv. 65, 81-82 (1970).

24. 77 Wash. $2 d$ at $315-16,462 \mathrm{P} .2 \mathrm{~d}$ at 238 . The theory that the artificial level should be treated the same as the natural level prevailed. Id.

25. Id. at 313-16, 322, 462 P.2d at 237-39, 242.

26. Shively v. Bowlby, 152 U.S. 1, 11-13 (1894). See R. HaLI, supra note 2, at 45-47; Stone, supra note 4, at 190-91.

27. Weber v. Board of Harbor Comm'rs, 85 U.S. (18 Wall.) 57 (1873); Pollard's Lessee v. Hagan, 44 U.S. (3 How.) 212 (1845); Martin v. Waddell, 41 U.S. (16 Pet.) 366 (1842); Ward v. Mulford, 32 Cal. 365 (1867). This title extended to the mean high-tide line. Borax Consol., Ltd. v. Los Angeles, 296 U.S. 10, 26-27 (1935). See also Stone, supra note 4, at 192, 194-95. 
exercise their control so as to preserve the public's common law rights. ${ }^{28}$ Thus, the public possesses an easement in all lands beneath navigable water ${ }^{29}$ regardless of ownership, ${ }^{30}$ which restricts such lands to uses that do not infringe the public right to "enjoy the navigation of the waters, carry on commerce over them, and have the liberty of fishing therein freed from the obstruction or interference of private parties." ${ }^{31}$

In adapting the common law rights im navigable waters, United States courts made several significant changes. Most importantly, the concept of navigable waters was expanded to include all waters navigable in fact. ${ }^{32}$ Secondly, a whole group of imcidental rights, princi-

28. Illinois Cent. R.R. v. Illinois, 146 U.S. 387, $452-53$ (1892). Sec also Stone, supra note 4, at 196-97. This requirement on the states is often spoken of as the "public trust." See, c.g., City of Long Beach v. Mansell, 3 Cal. 3d 462, 482, 476 P.2d 423, 437, 91 Cal. Rptr. 23, 37 (1970); Muench v. Public Serv. Comm'n, 261 Wis. 492, 501-03, 53 N.W.2d 514, 517-18 (1952).

29. People v. California Fish Co., 166 Cal. 576, 584, 138 P. 79, 82 (1913). See also Stone, supra note 4, at 208-10.

30. Oakland v. Oakland Water Front Co., 118 Cal. 160, 183, 50 P. 277, 285

(1897). See also Stone, supra note 4, at 209.

31. Illinois Cent. R.R. v. Illinois, 146 U.S. 387, 452 (1892).

32. The American definition of navigable water derives from the famous quotation in The Daniel Ball, 77 U.S. (10 Wall.) 557, 563 (1870). See note 5 supra. This is the rule used when determining rights that arise under the Constitution and federal law, and determines the extent of state ownership of lands under navigable waters when admitted to the Union. United States v. Holt State Bank, 270 U.S. 49, 55-56 (1926). The Daniel Ball rule has gradually become more expansive. See The Montello, 87 U.S. (20 Wall.) 430 (1874) (waters navigable in fact despite rapids and sand bars; type of commercial vessel capable of navigating river irrelevant); Economy Light \& Power Co. v. United States, 256 U.S. 113 (1921) (artificial obstructions irrelevant to determination of navigability; river need not be capable of navigation at all stages of water or all seasons of the year; present use for navigation not necessary). See also Ashwander v. TVA, 297 U.S. 288 (1936); United States v. Oregon, 295 U.S. 1 (1935); Arizona v. California, 283 U.S. 423 (1931); United States v. Utah, 283 U.S. 64 (1931); United States v. Hoit State Bank, 270 U.S. 49 (1926); Oklahoma v. Texas, 258 U.S. 574 (1922); United States v. Rio Grande Dam and Irrigation Co., 174 U.S. 690 (1899); Shively v. Bowlby, 152 U.S. 1 (1894). At the present time the rule has been expanded to the extent that water nonnavigable in fact is subject to federal regulation under the commerce clause if it is capable of being made navigable by reasonable improvements. United States v. Appalachian Elec. Power Co., 311 U.S. 377, 409 (1940). However, for determination of title, the test is navigability in fact at the time of admission to the Union. United States v. Oregon, 295 U.S. 1, 14-15 (1935); United States v. Utah, 283 U.S. 64, 75 (1931).

Since public navigation rights are based on navigable water and the state title is determined by the federal test, it might seem that the public rights are also to be measured by the federal test. But this lias not been the case. Rather, public rights are determined in each state by the applicable state test for navigable water [Donnelly v. United States, 288 U.S. 243, 262 (1913)], since the state is responsible for the protection of the public rights [lllinois Cent. R.R. v. Illinois, 146 U.S. $452-54$ (1892)] and there is no federal coinmon law governing navigable water [Willamette Iron Bridge Co. v. Hatch, 125 U.S. 1 (1888)]. State tests differ markedly despite the common reliance on a navigable-in-fact standard. Compare Resort Dev. Co. v. Parmele, 235 N.C. $689,695,71$ S.E.2d 474,479 (1952) ("[W]aters which are sufficient in fact to 
pally recreational ${ }^{33}$ but including commercial as well, ${ }^{34}$ were added for the public's benefit. Moreover, in some states the advance was carried full circle by defining as navigable all water useful for the exercise of recreational rights. ${ }^{35}$

At their outermost limit, then, common law navigation rights give the public a colorable clain to use any navigable lake, river, or seacoast for recreational purposes. However, the notion of state ownership of the land under navigable waters also made possible state sale to private individuals and opened up the possibility for a limitation of public

afford a common passage for people in sea vessels are to be considered navigable waters under the laws of this state.") with Muench v. Public Serv. Comm'n, 261 Wis. 492, 506, 53 N.W.2d 514, 519 (1952) ("[A]ny stream is 'navigable in fact' which is capable of floating any boat, skiff or canoe, of the shallowest draft used for recreational purposes"). These differences in turn determine the extent of public rights in any state's waters. For example, if a state requires use for commercial purposes for water to be navigable in fact [see, e.g., Fairchild v. Kraener, 11 App. Div. 2d 232, 204 N.Y.S.2d 823 (1960)], it eliminates from that category most of the waters in the state suitable for recreational uses, because most sunall lakes, reservoirs, and streains have no commercial transportation uses. For a good example of the confusion that these tests breed, see Bohn v. Albertson, 107 Cal. App. 2d 738, 745-48, 238 P.2d 128, 133-35 (1st Dist. 1951) (determination of navigability in fact relying on both commercial and recreational tests). Although this Comment restricts itself to navigable water and private filling, other approaches are available for nonnavigable water that will lead to the saine result. See Bach v. Sarich, 74 Wash. 2d 575, 445 P.2d 648 (1968). See generally Johnson \& Morry, Filling and Building on Small Lakes, 45 WASH. L. REv. 27 (1970); Note, Public Recreation and Subdivisions on Lakes and Reservoirs in California, 23 STAN. L. Rev. 811 (1971).

33. The move to include public recreation rights as part of or in addition to the public navigation right has not been uniform throughout the states. Some of the states that recognize recreation rights in one degree or another are: California [Bohn v. Albertson, 107 Cal. App. 2d 738, 238 P.2d 128 (1st Dist. 1951)]; Florida [Brickell v. Trammell, 77 Fla. 544, 82 So. 221 (1919)] Maine [Gratto v. Palangi, 54 Me. 308, 147 A.2d 455 (1958)]; Massachusetts [State v. Gunn, 170 Mass. 509, 49 N.E. 1017 (1898)]; Michigan [Kerley v. Wolfe, 349 Mich. 350, 84 N.W.2d 748 (1957)]; Minnesota [Nelson v. DeLong, 213 Minn. 425, 7 N.W.2d 342 (1942)]; New Hampshire [Whitcher v. State, 87 N.H. 405, 181 A. 549 (1935)]; New Mexico [State v. Red River Valley Co., 51 N.M. 207, 182 P.2d 421 (1945)]; New York [Fairchild v. Kraemer, 11 App. Div. 2d 232, 204 N.Y.S.2d 823 (1960)]; North Carolina [State v. Twiford, 136 N.C. 603, 48 S.E. 586 (1904)]; North Dakota [Roberts v. Taylor, 47 N.D. 146, 181 N.W. 622 (1921)]; Ohio [Mentor Harbor Yachting Club v. Mentor Lagoons, Inc., 170 Ohio St. 193, 163 N.E.2d 373 (1959)]; Oregon [Luscher v. Reynolds, 153 Ore. 625, 56 P.2d 1158 (1936) (dictum)]; South Dakota [Hillebrand v. Knapp, 65 S.D. 414, 274 N.W. 821 (1937)]; Vermont [State v. Malmquist, 114 Vt. 96, 40 A.2d 534 (1944)]; Washington [Wilbour v. Gallagher, 77 Wash. 2d 306, 462 P.2d 232 (1969)]; Wisconsin [Muench v. Public Serv. Comm'n, 261 Wis. 492, 53 N.W.2d 514 (1952)]; Wyoming [Day v. Armstrong, 362 P.2d 137 (Wyo. 1961)].

34. See, e.g., United States v. Appalachian Elec. Power Co., 311 U.S. 377, 404-05 (1940). This addition derives from the commerce clause of the Constitution.

35. See, e.g., Kerley v. Wolfe, 349 Mich. 350, 84 N.W.2d 748 (1957); Lamprey v. State (Metcalf), 52 Minn. 181, 53 N.W. 1139 (1893); Muench v. Public Serv. Comm'n, 261 Wis. 492, 53 N.W.2d 514 (1952). 
rights. $^{36}$ Furthermore, states generally allowed riparian owners to build wharves and other incidents in aid of navigation. ${ }^{37}$ This and the different state approaches to ownership raised the question to what degree, if any, a given state's action had inpaired the predominant public rights in the navigable water over privately held or privately improved land. ${ }^{38}$

The courts have failed to provide a clear answer to this crucial question, but any answer requires an inquiry into three subsidiary issues: the legal status of public navigation rights, the extent of those rights, and the definition of obstructions to navigation.

\section{The State's Fiduciary Duty to Protect Public Navigation Rights}

In Illinois Central Railroad v. Illinois, ${ }^{39}$ the Supreme Court identified the duty of a state to hold in trust the public common law rights in navigable waters. ${ }^{40}$ In 1883 , the state of Illinois sued to determine title to land comprising the harbor of Chicago and extending one mile into Lake Michigan - land the state had purported to convey to the Illinois Central Railroad in 1869.41 Declaring the original conveyance invalid, the Court characterized the state's title to land under its navigable waters as a "trust devolving upon the State for the public . . . which can only be discharged by the management and control of property in which the public lias an interest, [and] cannot be relinquished

36. As long as the state has not conveyed lands to private parties it cannot abandon its role as guardian of the public interest. Illinois Cent. R.R. v. Illinois, 146 U.S. 387, 452-54 (1892). This role gives the state "absolute" power to "control, regulate, and utilize such waters." Colberg, Inc. v. State $e x$ rel. Department of Pub. Works, 67 Cal. 2d 408, 416, 432 P.2d 3, 9, 62 Cal. Rptr. 401, 407 (1967), cert. denied, 390 U.S. 949 (1968). Property owners affected by the state's exercise of this power have no claim to compensation. Id. at $416-26,432$ P.2d at 8-15, 62 Cal. Rptr. at 406-13. The state may permit riparian or littoral owners to erect structures on state land in public waters without impairing public rights, which is usually done through explicit statutes. See, e.g., WIs. STaT. ANN. $\S \S 30.11$-13 (1964, Supp. 1970). The Wisconsin statutes are carefully drawn to assure protection of the public rights. See Wis. STat. ANN. \& 30.11(5) (requiring determination of the public interest). The common law rights to wharf out were subject to the public rights also. See Doemel v. Jantz, 180 Wis. 225, 193 N.W. 393 (1923). See note 64 infra. Thus, as long as the state has not absolutely conveyed its lands under navigable waters to private persons, the public rights remain. Cf. Mallon v. City of Long Beach, 44 Cal. 2d 199, 282 P.2d 481 (1955); Newcomb v. City of Newport Beach, 7 Cal. 2d 393, 60 P.2d 825 (1936); City of Coronado v. San Diego Unified Port Dist., 227 Cal. App. 2d 455, 38 Cal. Rptr. 834 (4th Dist. 1964).

37. Shively v. Bowlby, 152 U.S. 1, 18-26 (1894) (quiet title action seeking to determine title to land below the high-water mark of the Columbia River under a donatiou land grant from the federal government).

38. See, e.g., Illinois Cent. R.R. v. Illinois, 146 U.S. 387 (1892).

39. 146 U.S. 387 (1892).

40. Id. at 452 . See note 28 supra and accompanying text.

41. Id. at $448-49$. 
by a transfer of the property." 42 This responsibility derives from the state's original title to the land under its navigable waters, making it the equivalent of the sovereign at common law. ${ }^{43}$

Thus the state assumes a fiduciary duty that is frequently characterized as equivalent to that exercised over monetary trusts, with the public in the role of beneficiary. ${ }^{44}$ A state conveyance of land to private persons on the scale of that in Illinois Central is inconsistent with the trust rationale since it amounts to an abdication of state control. However, the Supreme Court noted that the state in the exercise of its management and control of these lands can dispose of them to promote "the interests of the public therem" or when no "substantial impairment of the public interest in the lands and waters remaining" results. ${ }^{45}$ As a result, the states were given great leeway in disposing of public trust lands as long as this was done in the guise of management and control, and the Court has not responded with more precise standards. ${ }^{46}$ Later cases specifically recognize the leeway in building wharves and other aids to navigation that individual states have given to owners of land bordering on navigable tidelands. ${ }^{47}$ Thus, it is the state that defines the further requirements its public trust actions must meet. This im turn has led to situations similar to that faced in Wilbour-fills constructed in navigable waters where the riparian or littoral owner holds title to the land beneath the navigable water. ${ }^{48}$

The rule in some states, notably California, is that the state holds the land under its navigable waters in trust for the people of the state, ${ }^{49}$ which imposes an easement on owners of land under navigable waters where the owner has received his title through alienation by the state. ${ }^{50}$

42. Id. at 453 .

43. Id. at 435, 452-54. See also Weber v. Board of Harbor Comm'rs, 85 U.S. (18 Wall.) 57 (1873); Pollard's Lessee v. Hagan, 44 U.S. (3 How.) 212 (1845); Martin v. Waddell, 41 U.S. (16 Pet.) 366 (1842).

44. Mallon v. City of Long Beach, 44 Cal. 2d 199, 208, 282 P.2d 481, 486-87 (1955); cf. Muench v. Public Serv. Comm'n, 261 Wis. 492, 511-12, 53 N.W.2d 514, 522 (1952).

45. Illinois Cent. R.R. v. Illinois, 146 U.S. 387, 452-53 (1892).

46. See also Sax, supra note 7, at 489-91.

47. United States v. Rio Grande Irrigation Co., 174 U.S. 690, 702-03 (1899); Prosser v. Northern Pac. R.R., 152 U.S. 59 (1894); Shively v. Bowlby, 152 U.S. 1 (1894).

48. See, e.g., Alameda Conservation Ass'n v. City of Alameda, 264 Cal. App. 2d 284, 70 Cal. Rptr. 264 (1st Dist.), cert. denied, 394 U.S. 906 (1968) (filling and dredging San Francisco Bay). Even Illinois Cent. R.R. v. Illinois, 146 U.S. 387 (1892), approved some filling and piers in Lake Michigan. Id. at 439-48, 464. See also Shively v. Bowlby, 152 U.S. 1, 18-26 (1893).

49. People v. California Fish Co., 166 Cal. 576, 584, 138 P. 79, 82 (1913).

50. Id. This holding is based in part on a specific provision of the California Constitution that retains an easement in all tidelands granted to private parties. See notes $157-61$ infra and accompanying text. 
This easement rationale should make direct injunctive relief available against private interference with public navigation rights, ${ }^{\text {,1 }}$ but even a pure pubhic-trust state such as Wisconsin ${ }^{52}$ has inade such relief available without resort to the easement doctrine. ${ }^{63}$ Under both theories the public rights are treated as a property right, allowing in appropriate circumstances injunctive relief, ${ }^{54}$ prescriptive rights in artifically created navigable water, ${ }^{56}$ and state enforcement of public trust duties. ${ }^{60}$

\section{The Extent of Particular Public Rights}

The expansion of the definition of navigability and the inclusion by soine states of recreational uses as navigation rights ${ }^{57}$ has created confusion and conflict anong the states over whether these newer rights should be exercised in all water now classified as navigable. Although navigable waters are held to extend to the high-water mark, ${ }^{58}$ not all the rights are capable of being exercised over the whole of the water. ${ }^{50}$ Thus it was once thought that public rights in navigable waters where the bed was privately owned, were confined to actual navigation-excluding recreational uses. ${ }^{60}$ Today this view has generally been repudiated ${ }^{61}$ and the argument centers around whether the public may use all water suitable for recreation regardless of its ownership and classifica-

51. Cf. Forestier v. Johnson, 164 Cal. 24, 127 P. 156 (1912); Alameda Conservation Ass'n v. Alameda, 264 Cal. App. 2d 284, 70 Cal. Rptr. 264 (1st Dist. 1968); Bohn v. Albertson, 107 Cal. App. 2d 738, 238 P.2d 128 (1st Dist. 1951).

52. See Muench v. Public Serv. Comm'n, 261 Wis. 492, 501-02, 53 N.W.2d 514, 517 (1952). See generally Sax, supra note 7, at 509-23.

53. Muench v. Pubbic Serv. Comm'n, 261 Wis. 492, 511-12, 53 N.W.2d 514, 522 (1952). See also Waite, Public Rights to Use and Have Access to Navigable Waters, 1958 WIs. L. REv. 335, 337-60.

54. Baker v. Voss, 217 Wis. 415, 417, 259 N.W. 413, 414 (1935); Village of Pewaukee v. Savoy, 103 Wis. 271, 279-80, 79 N.W. 436, 439 (1899).

55. See Haase v. Kingston Co-operative Creamery Ass'n, 212 Wis. 585, 588-89, 250 N.W. 444, 445 (1933). This decision apparently ovcrruled the holding in Pewaukee that the title to the land under the artificially raised water had passed to the state by prescription, but carefully pointed out that "this rule does not deprive the public of any rights. ... Such right as the public has acquired will be fully protected by the ordinary remedies." Id. at 589, 250 N.W. at 445 . See also Smith v. Youmans, 96 Wis. 103,70 N.W. 1115 (1897).

56. See Oakland v. Oakland Water Front Co., 118 Cal. 160, 56 P. 277 (1897) (an attempted alienation of large tideland areas by a municipal authority); cf. Illinois Cent. R.R. v. Illinois, 146 U.S. 387 (1892).

57. See note 33 supra and accompanying text.

58. Shively v. Bowlby, 152 U.S. 1, 11 (1894); see Stone, supra note 4, at 192, 194-95. See also authorities cited note 27 supra.

59. Soine of the uses mentioned in the cases cited note 33 supra include swimming, hunting, fishing, sailing, boating, cutting ice, water skiing, skin diving, canoeing, and skating as well as general transportation.

60. See 30 MrCH. L. REv. 472, 473 (1932) and cases cited therein.

61. See Stone, supra note 4, at 209. 
tion under navigable-in-fact standards. ${ }^{62}$ From the public rights standpoint an optimal, but circular, definition of navigable water would be correlated with the uses that are being asserted. ${ }^{63}$ Where the navigation rights being considered are for transportation, waters capable of such use would be navigable. Where the right is swimming, then waters capable of use for swimming would be navigable even though those waters are not navigable for other purposes.

This approach, however, ignores the rights and justified expectations of riparian and littoral owners. ${ }^{64}$ Therefore, it is preferable to view recreation rights as deriving from traditional navigation rights, of which any owner on navigable water has notice due to their long-standing acceptance..$^{65}$

If a state, through legislative or judicial action, seeks to permit public use of waters that are not navigable in fact under its standards, ${ }^{66}$ it should purchase the land under eminent domain proceedings or the public inust acquire it under other legal theories. ${ }^{67}$ This requirement,

62. Compare Day v. Armstrong, 362 P.2d 137, 147 (Wyo. 1961) ("Irrespective of the ownership of the bed or channel of waters, and irrespective of their navigability, the public has the right to use pnblic waters of this State for floating usable craft. . ..") with Baker v. Normanoch Ass'n, 25 N.J. 407, 415, 136 A.2d 645, 650 (1957) ("[T]he general pubiic has no rights to the recreational use of a private lake"). See generally Comment, Water Recreation-Public Use of "Private" Waters, 52 CaLIF. L. REv. 171 (1964).

63. The original definition of navigable water was based on its use for comnercial transportation, that being synonymous with "navigation." See The Daniel Ball, 77 U.S. (10 Wall.) 557 (1870). Under the commerce clause test for navigability, all waters that could be used for activities that affect commerce are navigable. United States v. Appalachian Elec. Power Co., 311 U.S. 377 (1940). But except in the few public water states [see note 35 supra], the modern addition of recreational navigation rights has not caused the definition to be altered to correspond with their range of application. Thus, the definition of permissible public uses often includes recreation, while the navigable-in-fact test retains the older "useful for transportation" connotation, soinetimes with much confusion. See, e.g., Bohn v. Albertson, 107 Cal. App. 2d 738, 745-48, 238 P.2d 128, 133-35 (1st Dist. 1951).

64. The right to wharf out to navigable water is frequently mentioned. See Greenleaf-Johnson Lumber Co. v. Garrison, 237 U.S. 251 (1915). See also Stone, supra note 4 , at $42-43$. This right is usually qualified by the public navigation rights. See, e.g., People v. Southern Pac. R.R., 166 Cal. 627, 138 P. 103 (1913). It derives from the older definitions of navigability and therefore is confused at present. The resulting conflict of expectations is the primary cause for litigation like Wilbour $v$. Gallagher, although in Washington there are no riparian rights on navigable water. Eisenbach v. Hatfield, 2 Wash. 236, 26 P. 539 (1891).

65. The Wilbour court did not face this issue since the water was conceded to be navigable. 77 Wash. $2 \mathrm{~d}$ at $307,462 \mathrm{P} .2 \mathrm{~d}$ at 233 .

66. See note 32 supra and accompanying text.

67. See, e.g., Wilbour v. Gallagher, 77 Wash. $2 \mathrm{~d}$ at $318-22,462$ P.2d at $240-42$ (1969) (dissenting opinion). The dissent in Wilbour makes this point vigorously, arguing that no public rights exist in land periodically overflowed:

Here, the defendants' lots, all of which lie above natural high water, are not subject to public navigation rights unless there has been a voluntary convey- 
however, still allows states to make creative use of their varied navigable-in-fact standards by adjusting the definition to meet their particular circumstances. ${ }^{68}$ For example, a state wishing to secure public opportunity to use its many small lakes could classify all waters capable of public use as navigable in fact. On the other hand, a state leavily dependent on commercial shipping might wish to classify as navigable in fact only the navigable channels of rivers and mlets, thus freeing the shallow shore areas for industrial development. The expectations of riparian and littoral owners are protected since changes in the common law navigability standards will gradually reflect actual changes in public priorities. The issue of the extent of the public rights is therefore best handled through the flexible navigable-in-fact definition, and pubhic recreational rights should not extend beyond the more customary rights froin which they derive.

\section{What Constitutes an Obstruction to Navigation?}

The Wilbour court was unconcerned whether the fills in the case were obstructions to navigation because it took a broad view of navigation and because it felt interference with the "mcidental rights" of navigation was on a par with interference with actual navigation. ${ }^{70}$ The inclusion of interference with public recreational uses as an obstruction to navigation is not a burden on holders of land under navigable waters, as they should be well aware that public rights exist. ${ }^{71}$ A narrow

ance, eminent domain proceedings, estoppel, or loss through prescription.

Id. at 321, 462 P.2d at 242 (emphasis in origmal). For further discussion of this contention, see notes 85-114 infra and accompanying text.

68. See, e.g., People ex rel. Baker v. Mack, 19 Cal. App. 3d 1040, 97 Cal. Rptr. 448 (3d Dist. 1971). Defendants, riparian owners on Fall River in Shasta County, erected booms, fences, and low bridges across the river, claiming it was unnavigable. The court of appeals, noting that "[t]he streams of California are a vital recreational resource of the state," declared all waters "capable of being navigated by oar or motor propelled small craft" navigable [id. at 1050, 97 Cal. Rptr. at 454] despite early California authority supporting a useful-for-commercial-purposes test. See Wright v. Seymour, 69 Cal. 122, 10 P. 323 (1886); Ford v. County of Butte, 62 Cal. App. 2d 638, 145 P.2d 640 (1st Dist. 1944).

69. 77 Wash. $2 \mathrm{~d}$ at 316,462 P.2d at 239.

70. The commou law distinguished between an obstruction to commercial navigation, which was classified as a uuisance, and a structure on sovereign land that did not actually interfere with shipping, which was denominated a purpresture. See, c.g., State v. Carpenter, 68 Wis. 165, 31 N.W. 730 (1887). An injunction and abatemeut were available against both at common law, but such rehef has been denicd as against a purpresture where the state no longer holds title to the soil under the navigable water. Id. However, where the state or a subdivision of the state still holds title to such lands, it may at its discretion order the removal of structures as purprestures even though there is no interference with actual navigation. County of Marin v. Roberts, 4 Cal. App. 3d 480, 84 Cal. Rptr. 425 (1st Dist. 1970).

71. See text accompanying note 64 supra. The language of a typical nuisance statute is broad enough to cover interference with recreational uses of navigable watcr. 
definition of what constitutes an obstruction to navigation ${ }^{72}$ could effectively eliminate the incidental navigation rights as well as the traditional right of fishing. ${ }^{73}$ In the Lake Chelan instance and all cases of private ownership of lakes and bays below the high-water inark, such a view permits the possibility of unrestrained filling and building on the land between the high- and low-water nnarks, destroying nuch of their public value. $^{74}$ Thus the interference with public recreational uses that fills cause should constitute an obstruction to navigation.

\section{B. Public Rights in Fluctuating Water}

The possibility for conflict between public navigation rights and private land ownership is most acute where the water level fluctuates. When the water is at a low level, the private owner may assert a right to exclusive use of the property, smce the public has rights only to use of the water. Despite the long-standing acceptance of public rights in tidelands, ${ }^{75}$ it was not until public navigation rights were extended to inland navigable lakes ${ }^{76}$ that the coinpeting public and private rights were clarified. The Wilbour court adopted the prevailing explanation that where the water level of a navigable lake fluctuates naturally, the public rights follow the water. ${ }^{77}$ Whether a riparian or littoral ${ }^{78}$ owns to the high- or to the low-water mark, he has no right to exclude the public from navigating on the water over his property. ${ }^{79}$ At the same tine, if he does own to the low-water mark, he inay exclude trespassers from his property when it is not covered by water. ${ }^{80}$

See, e.g., CaL. CTV. CODE $\$ 3479$ (West 1954) ("Anything which . . . unlawfully obstructs the free passage or use, in the customary manner, of any navigable lake, or river, bay, stream, canal, or basin . . . is a nuisance") (emphasis added). In Wilbour, the Gallaghers' fill rendered the previous public use of the area for swimming, fishing, and boating impossible, and thus clearly "obstructed" such use.

72. Perhaps a fill should be viewed as a removal of the water from any public nse rather than an obstruction of the public use. Either terminology should lead a conrt to the same result-that the action is a nuisance and subject to abatement.

73. Sce State v. Malmquist, 114 Vt. 96, 40 A.2d 534 (1944).

74. 77 Wash. $2 \mathrm{~d}$ at $312-13,462$ P.2d at 237. The court recognized that deciding against the public could entail precisely this result. Id. at $316 \mathrm{n} .13,462 \mathrm{P} .2 \mathrm{~d}$ at 239 n.13. See note 117 infra.

75. The whole public trust doctrine originated as a tidelands trust. See R. Hall, supra note 2, at 45-47; Note, The Public Trust in Tidal Areas, 79 YALE L.J. 762 (1970).

76. Hardin v. Jordan, 140 U.S. 371, 381-82 (1891); cf. Barney v. Keokuk, 94 U.S. 324 (1876); Churchill Co. v. Kingsbury, 178 Cal. 554, 174 P. 329 (1918). See generally Shively v. Bowlby, 152 U.S. 1 (1894).

77. See, e.g., Doemel v. Jantz, 180 Wis. 225, 235, 193 N.W. 393, 397 (1923); Diana Shooting Club v. Husting, 156 Wis. 261, 272, 145 N.W. 816, 820 (1914).

78. Generally a riparian owner is one who owns property on the bank of a river, while a littoral owner owns land on the shore of the ocean or large lakes. But "riparian" is also used coextensively with "littoral".

79. Doemel v. Jantz, 180 Wis. 225, 235, 193 N.W. 393, 397 (1923).

80. Id. at 237,193 N.W. at 398; Stewart v. Turney, 237 N.Y. 117,142 N.E. 
This view, although strictly speaking correct, may be misleading. The rights of the public and private owner do not vary with the water level; the public right is always predominant and restricts the owner's right to use his property as he chooses. ${ }^{81}$ The owner's right is to possession of his property; he may assert this right against the public, however, only when his property is exposed. In this way, the courts have accominodated public rights in navigable water with notions of private ownership. However, the rights of the public can be assured only when restrictions are placed on the owner's use of his property during the period of exclusive possession. The Wilbour court recognized this and held that even when it is exposed, the owner is prohibited from using his property in a manner inconsistent with the right of the public to use the navigable water when it does cover his property. ${ }^{82}$ Thus the riparian or littoral who owns below the high-water mark nay not build upon his land when it is dry. ${ }^{83}$ The rights of such owners on naturally fluctuating navigable water are qualified by public navigation rights in the region between high and low water.

\section{Public Rights in Artificial Water}

The Wilbour court recognized that any explanation of riparian, littoral, and public rights in naturally fluctuating water does not automatically apply to water that fluctuates artificially, such as Lake Chelan. ${ }^{84}$ Since there was no direct Washington authority on this point, the court looked to other states for cases dealing with an artificial raising of water levels on a permanent or long-term basis. The court rehed primarily on an early Wisconsin case, Mendota Club v. Anderson. ${ }^{85}$ In that case a trespass action was brought against members of the public who hunted from boats on the water above property claimed by plaintiffs. A dain that raised the water level had been built 47 years before, ${ }^{86}$ and the court held that maintenance of the water at its artificial

437 (1923). The Wilbour court expressed the principle in this way:

IIn the situation of a naturally varying water level, the respective rights of the public and of the owners of the periodically submerged lands are dependeut upon the level of the water. As the level rises, the rights of the public to use the water increase since the area of the water increases; correspondingly, the rights of the landowners decrease since they cannot use their property in such a manner as to interfere with the expanded public rights. As the level and area of the water decreases, the rights of the public decrease and the rights of the landowner increase as the waters drain off their land, again giving them the right to exclusive possession until their lands are again subinerged.

77 Wash. $2 \mathrm{~d}$ at 315,462 P.2d at 238.

81. Carpenter v. Board of Comm'rs, 58 N.W. 295, 296 (Minn. 1894).

82. 77 Wash. $2 d$ at 316,462 P.2d at 239.

83. Id. But see Stewart v. Turney, 237 N.Y. 117, 142 N.E. 437 (1923).

84. 77 Wash. $2 \mathrm{~d}$ at $313-14,462$ P.2d at 237.

85. 101 Wis. 479,78 N.W. 185 (1899).

86. Id. at 493,78 N.W. at $189-90$. 
level gave the public "the right to navigate such waters after they were so increased in volume, the same as though they had always remained in that condition." 87 The court specifically reserved judgment as to whether the riparian owner could fill in or build out to the line of natural navigability. ${ }^{88}$ This decision is consistent with the fluctuating water cases holding that the public rights follow the navigable water. ${ }^{89}$

Although not cited in Wilbour, another Wisconsin decision later that same year provides even stronger support for public riglits in an artificial lake. In Village of Pewaukee v. Savoy, ${ }^{90}$ the complaining landowner was a successor in title to the owner who originally caused the level of the lake to be raised. ${ }^{91}$ Not only did the court find that the public had the right to go upon the full extent of the lake, whether its level was artificially raised or not, ${ }^{92}$ but it also concluded that if an owner of land on a lake creates an artificially high water level flooding some of his land, his actions create a presumption that he intends to dedicate the land to public use. ${ }^{93}$ Furthermore, the court held that "[u]ninterrupted and contmuous use acquiesced in for 20 years, constitutes conclusive proof of dedication." were reaffirmed in State $v$. Malmquist, ${ }^{95}$ where Verinont successfully prevented the proprietor of a dam from lowering the water level that

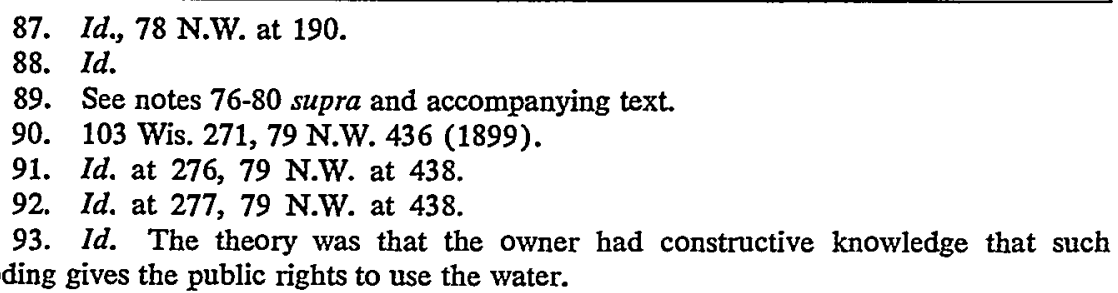
flooding gives the public rights to use the water.

94. Id. Twenty years is the prescriptive period in Wisconsin. A similar doctrine exists in California. See Schwerdtle v. County of Placer, 108 Cal. 589, 41 P. 448 (1895). But it has been rejected elsewhere. State ex rel. Thornton v. Hay, 254 Ore. 584, 462 P.2d $671(1969)$. Thus, the court held that the owners who maintained the lake level for 50 years dedicated their land to the public. 103 Wis. at 278,79 N.W. at 438. As indicated in note 55 supra, the Pewaukee reasoning was rejected in Haase v. Kingston Co-operative Creamery Ass'n, 212 Wis. 585, 588-89, 250 N.W. 444, 445 (1933):

[W] here the owner of land creates an artificial body of water upon his own prenises, he may permit the public to enjoy the ordinary use of such waters, and it may be that by the lapse of time such enjoyment will ripen into a dedication which he will not be permitted to destroy. But such a use of the waters does not amount to an adverse possession in favor of the state giving the state title to the land under the waters, and, so far as previous decisions to the contrary are concerned, they are hereby overruled.

The extent to which Pewaukee is overruled is unclear since its decision did not depend exclusively on adverse possession. See text accompanying notes 85-89 supra, 95-98 infra. Moreover, the prescription rationale is clearly disfavored. See note 23 supra. However, the Haase court insisted that no public rights were jeopardized by its holding. ld. at 587-89, 250 N.W. at 445. See also Smith v. Youmans, 96 Wis. 103, 70 N.W. 1115 (1897).

95. 114 Vt. 96,40 A.2d 534 (1944). 
had been maintained for 40 years. ${ }^{96}$ The court held that the artificial level had in fact become the natural level as regards "the common rights of fishing and navigation and to all other incidents of public water"97 and that a lowering of the level that would impair these rights was a public nuisance. ${ }^{98}$

From these cases a group of possible factors emerge for evaluating the extent of public rights in navigable waters where the water level is created artificially. These include the length of time the water has remained at a particular level, ${ }^{99}$ the relation of the littoral owner to the person or entity responsible for the level, the time the present littoral owner acquired his title, and the intentions of the persons originally creating the artificial level and the present littoral owners. What weight should be accorded these factors is suggested in Bohn v. Albertson, ${ }^{100}$ a California decision regarding public rights in a navigable water created by a severe flood. ${ }^{101}$ After initially determining that the flooded area was navigable, ${ }^{102}$ the court considered the property owner's claim that he could exclule the public from the waters over his property. ${ }^{103}$ The court concluded that "although the title to the lands thereunder still remains in the owners and they have the right to reclaim, the public, until the land is reclaimed, has the right of navigation and fisliery." 104

The factual situation in Bohn is indistinguishable from that of a littoral owner whose land is flooded by construction of a dain over which he has no control. Since all these cases hold that any navigable water whether artificial or natural, temporary or permanent, is open to public use for the purposes of navigation, the crucial question is: May the littoral or riparian owner reclaim his property that has become flooded? According to Bohn, the answer turns on whether the littoral owner or his predecessor in title were and remain responsible for the flooding. If he was, ${ }^{105}$ there is a presumed dedication to the public

96. Id. at 102, $40 \mathrm{~A} .2 \mathrm{~d}$ at 538. The water level fluctuated between two and three feet. Id. at 100, 40 A.2d at 537 . Club. Id.

97. Id. at 102, 40 A.2d at 538. The court relied on Pewaukee and Mendota

98. Id. The court also held the state was entitled to injunctive relief. Id. at 105, 40 A.2d at 540.

99. This time is especially important in relation to the state prescriptive period. See Village of Pewaukee v. Savoy, 103 Wis. 271, 79 N.W. 436 (1899).

100. 107 Cal. App. 2d 738, 238 P.2d 128 (1st Dist. 1951).

101. Id. at 739,238 P.2d at 129 . Plamtiffs leased the land nine years after it had been flooded. Id. at 740,238 P.2d at 130 .

102. Id. at 748,238 P.2d at 135 . See note 32 supra.

103. Id. at 749,238 P.2d at 135 .

104. Id.

105. This was the situation in all the dam cases except Mendota Club v. Anderson, 101 Wis. 479, 78 N.W. 185 (1899). 
and no right to reclaim. ${ }^{106}$ If he was not responsible, the present owner has a right to reclaim the land and terminate the public use ${ }^{107}$ even though he could have controlled the water level had he taken positive action $^{108}$ and even though the property has been flooded for the prescriptive period. ${ }^{109}$

Even Bohn fails to give a clear-cut answer where the present owner acquired the property subsequent to flooding by the predecessor in title over which the present owner now has no control-and this was precisely the situation in Wilbour v. Gallagher. The Wilbour court combined these two areas of the law-public rights in naturally fluctuating water and pubhic rights in water at an artificial level-to reach the "logical"110 result that riparian owners cannot fill their land at low water to interfere with public navigation rights at high water. ${ }^{111}$ But the court merely mechanically combined the theories of these two areas and failed to analyze the factors that can give the result a sound basis. The factors discussed above clearly demand that the Wilbour defendants should not have the right to reclaim. They were successors in title to the power company, which was initially responsible for the periodic flooding. ${ }^{112}$ They took with full knowledge that the property was periodically flooded and that public use ${ }^{113}$ had continued for the prescriptive period. ${ }^{114}$ These factors establish that they should be treated as though they were initially responsible for the flooding. As the foregoing discussion indicates, public rights in fluctuating natural water, the factor focused upon by the Wilbour court, do not conclusively determine rights in fluctuating artificial water, and public rights in artificial

106. See Village of Pewaukee v. Savoy, 103 Wis. 271, 79 N.W. 436 (1899); cf. Haase v. Kingston Co-operative Creamery Ass'n, 212 Wis. 585, 588-89, 250 N.W. 444, 445 (1933) (overrules Pewaukee only on adverse possession, not dedication of the water to public use [see note 94 supra]). This probably requires a situation where the land has been flooded for the prescriptive period.

107. Bohn v. Albertson, 107 Cal. App. $2 d$ 738, 749, 238 P.2d 128, 135 (1st Dist. 1951).

108. See, e.g., id. at $739-40,238$ P.2d at 129-30.

109. Id. The prescriptive period in California is five years. CAL. CODE Crv. Pro. § 321 (West 1967).

110. 77 Wash. $2 d$ at 315,462 P.2d at 238 .

111. Id. at 316,462 P.2d at 239.

112. Furthermore, the power company had indicated an intent to dedicate the property or parts of it to the public. Before the construction of the dam, the city, which then held title to the streets and alleys in the area to be flooded, vacated them so that they reverted to the adjoining property owner, the power company. Id. at 307, 462 P.2d at 233-34. The same day, the power company executed an instrument conveying a right of access to the public over the streets and alleys at all stages of water. Id. at 307-08, $462 \mathrm{P} .2 \mathrm{~d}$ at 234 . Even the dissent agreed that this instrument created superior public rights to the streets and alleys that required the fills there be abated. Id. at 322, 462 P.2d at 242.

113. See note 16 supra and accompanying text.

114. See note 19 supra. 
water levels do not determine those rights when the level fluctuates. By focusing on the right to reclaim land under flooded waters, an answer is more readily available.

With this reconstruction, the doctrine of Wilbour $v$. Gallagher can be seen in its proper perspective. Whenever a private individual owns land beneath navigable waters - which include all waters navigable in fact-the owner may not use the property in a way that will interfere with the permissible public uses that attend any navigable water. This restriction applies even when the water level fluctuates, and even when the water level has been artificially affected, if the owner or his predecessor initiated the activity and either the land has been flooded for the prescriptive period or the present owner has knowledge of his predecessor's dedication. In particular, such an owner may not fill or prevent the submersion of lis land without public sanction.

Despite the apparent scope of this doctrine, it must be noted that there was no state involvement in Wilbour. The land had neither been sold by the state ${ }^{115}$ nor was there any autlorization for the Gallaghers' action. ${ }^{116}$ This observation raises the difficult question that the Wilbour court was able to ignore: to what extent can the state ${ }^{17}$ as proprieter of the public trust ${ }^{118}$ relinquish the public rights in navigable waters? ${ }^{119}$ It is only after studying the limitations of the Wilbour doctrine that its true extent, and lience its value as a regulator of private development, can be determined.

\section{II}

\section{Limitations on the Holding: Wilbour in California}

Although the particular facts of the Lake Chelan case are untikely to recur, ${ }^{120}$ Wilbour has potential impact wherever private owners at-

115. See note 11 supra.

116. See note 11 supra.

117. The court was concerned that the state had taken no role in the litigation, which left the court with two unpleasant choices: It could either uphold the private owner's right to build on his property, thus allowing all private owners around the lake to exclude the public from the use of the area when the land is submerged, or decide that the owner could not use his property in a manner inconsistent with the public uses, thus rendering his property virtually worthless to him. 77 Wash. $2 \mathrm{~d}$ at $316 \mathrm{n.13}$, 462 P.2d at 239 n.13. The court suggested that proper state regulation would permit some filling while preserving public recreation opportunities. Id. See note 36 supra.

118. See text accompanying notes $39-44$ supra.

119. The most effective way the state can try to do this is by selling the land beneath navigable waters and pernitting filling by the purchaser. See also note 36 supra for other methods of impairing public rights.

120. This may overstate the uniqueness of Wilbour v. Gallagher. Mendota Club v. Anderson, 101 Wis. 479, 78 N.W. 185 (1899), and Village of Pewaukee v. Savoy, 103 Wis. 271, 79 N.W. 436 (1899), both involved public and private rights on lakes whose levels had been raised so that privately owned lands were flooded. See notes 
tempt to construct fills in navigable waters. Its value should be greatest where the pressures and opportunities for development are most intense: seacoasts and lakes. ${ }^{121}$ But the problems of a wholesale application of Wilbour in these circumstances are significant. California, which makes explicit in its constitution the rights of the public in navigable waters, ${ }^{122}$ is a prime place to examine the possible relevance of the Wilbour doctrine that private fills in navigable waters are an obstruction to navigation. Public navigation rights were recognized early in California. ${ }^{123}$ At the same time, however, the state began selling its

85-94 supra and accompanying text. Perhaps the most familiar place where a Wilbour situation exists is Lake Tahoe in Cahfornia and Nevada. Although a natural navigable lake [30 OP. CAL. ATT'Y GEN. 262, 263 (1957)], a concrete dam in existence since 1912 has in general raised the water level six feet [id. at 264-68]. The 1957 opinion by the California attorney general concerning the rights of littoral owners relied on Smith v. Youmans, 96 Wis. 103, 70 N.W. 1115 (1897), for the proposition that an artificial water level maintained for a sufficient period becomes the equivalent of the natural level. 30 Op. CAL. ATT'Y GEN. at 273. Since Youmans was the basis of all the later Wisconsin cases involving public rights in artificial waters [see notes 85-94 supra and accompanying text], California will probably apply the law similarly. The only specific authority for this point, however, is National Soda Prods. Co. v. City of Los Angeles, 23 Cal. 2d 193, 143 P.2d 12 (1943). That case involved danage done to property when a dry lake was flooded by water released from a dam. In deciding that the flooded owners were entitled to dannages, the court rehed in part on Smith v. Youmans, concluding:

It is generally recognized that one who makes substantial expenditures in rehance on long-continued diversion of water by another has the right to have the diversion continued if his investment would otherwise be destroyed. ... A change in the flow of a stream that appears to be permanent usually leads to costly adjustments by those interested, as they come to regard the artificial condition as permanent. It is therefore reasonable that they should receive as inuch protection as if the condition were natural. . . .

Id. at 197, 143 P.2d at 15-16. This result does not precisely answer the question of the status of public rights where imjunctive rehef is sought rather than or in addition to damages. The Wisconsin cases indicate that such relief is available. See notes 85-94 supra and accompanying text. The California attorney general's opinion gives the same impression. 30 OP. CAL. ATT'Y GEN. at 272-74. Taken together, these authorities indicate that the law that will be applied regarding the artificial water level in Lake Tahoe is the same as was applied in Wilbour $v$. Gallagher. Therefore, building and other projects that require filling of the lake must obtain state consent or be subject to abatement.

121. The rights of the public in artificially fluctuating navigable water apply by defimition to naturally fluctuating navigable water. The law governing the former derives froin the law governing the latter. See notes 39-83 supra and accompanying text.

122. CAL. Const. art. XV, § 2:

No individual, partnership, or corporation, claiming or possessing the frontage or tidal lands of a harbor, bay, inlet, estuary, or other navigable water in this State, shall be permitted to exclude the right of way to such water whenever it is required for any public purpose, nor to destroy or obstruct the free navigation of such water; and the Legislature shall enact such laws as will give the most liberal construction to this provision, so that access to the navigable waters of this State shall be always attainable for the people thereof.

See also Cal. Const. art. XV, $\$ 3$.

123. See Eldridge v. Cowell, 4 Cal. 80,87 (1854). This case deals with property 
tidelands and other navigable waters into private ownership and terminating any public rights therein. ${ }^{124}$ No California court has ever held a private fill to be an obstruction to navigation.

The California experience indicates at least three major limitations to any universal application of Wilbour to navigable waters. First, pubhic navigation rights may be inappropriate for some navigable waters due to the physical nature of the submerged land. ${ }^{125}$ Second, and most important, the state, if it clearly intends to do so, may have the power in the interest of navigation to extinguish any public rights in property under navigable water and sell it into private ownership. ${ }^{120}$ Third, an estoppel may arise against the state in attempting to assert the public rights if the state has acquiesced in the fill. ${ }^{127}$

\section{A. The Physical Features of the Land}

The earliest California cases, ${ }^{128}$ decided over a century ago, recognized the ambiguous position that caine to characterize the state's law of navigable waters: the state has a duty to preserve the public com-

formerly submerged under navigable water that apparently had already been sold outright imto private ownership.

124. Sales may have occurred as early as 1847. M. ScorT, supra note 6, at 1-2. The property imvolved in Eldridge $v$. Cowell was submerged land that had been sold into private ownership. See note 123 supra. In 1850 Congress passed the Arkansas Swamp Lands Act transferring federally owned swamplands to the states [Act of Sept. 28,1850 , ch. $84, \S 4,9$ Stat. 519], and beginning in 1855 California surveyed and sold these lands into private ownership for diking, filling, and reclaiming. Act of April 28, 1855, ch. 151, [1855] Cal. Stat. 189. Although the acts were restricted to the sale of swainp and overflowed land, many navigable sloughs and some submerged lands were included in the surveys and sold. $M$. Scort, supra note 6 , at 4; San Francisco Bay Conservation and Development Commission, San Francisco Bay Plan Supplement 436, January 1969 [hereinafter cited as BCDC Supplement]. Many of these were subsequently filled. BCDC Supplement 436 . Later statutes specifically noted that tidelands had been accidently surveyed, and segregated the funds from such sales. Act of April 21, 1858, ch. 235, $\$ 1$, [1858] Cal. Stat. 198. The first act explicitly authorizing widespread sales of tidelands was passed in 1861 [Act of May 14, 1861, ch. 356, [1861] Cal. Stat. 363], and tidelands continued to be sold until 1909. Political Code $\$ 3443 \mathrm{a}$, added by ch. 444, $\$ 1$, [1909] Cal. Stat. 744 (now CaL. Pup. RES. CODE $\$ 7991$ (West 1956)). For summaries of these sales see M. ScoTt, supra note 6, at 1-7, 11-20, 117-25; BCDC Supplement 427-34. Although California naviga. ble water law deals almost exclusively with tidelands, it is equally applicable to navigable lakes. See Churchill Co. v. Kingsbury, 178 Cal. 554, 558, 174 P. 329, 330 (1918).

125. Ward v. Mulford, 32 Cal. 365, 373 (1867). See notes 131-41 infra and accompanying text.

126. See Knudson v. Kearney, 171 Cal. 250, 252-53, 152 P. 541,542 (1915); Ward v. Mulford, 32 Cal. 365, $372-73$ (1867); Eldridge v. Cowell, 4 Cal. 80, 87 (1854). See notes 142-90 infra and accompanying text.

127. See City of Long Beach v. Mansell, 3 Cal. 3d 462, 487-501, 476 P.2d 423, 441-51, 91 Cal. Rptr. 23, $41-51$ (1970). See notes 196-210 infra and accompanying text.

128. See, e.g., Ward v. Mulford, 32 Cal. 365 (1867); Teschemacher v. Thompson, $18 \mathrm{Cal} .11$ (1861); Eldridge v. Cowell, 4 Cal. 80 (1854). 
mon law navigation rights, but, in the exercise of its sovereign power over such waters, it may destroy the public rights and create absolute private ownership. ${ }^{129}$ These early courts did not explain the circumstances under which public rights could be compromised, ${ }^{130}$ but they partially resolved this tension between these two positions by creating an exception to the public rights where the land in question was unsuited to the exercise of such rights.

In Ward v. Mulford ${ }^{131}$ a state grant of a tidal salt pond was upheld. After reaffirming the state commitment to preserve the public rights of navigation and fishery, the court held that the state may grant to a private individual land under navigable waters that are not fit for navigation. Sucl land, the court stated, could be reclaimed without prejudice to the public right. ${ }^{132}$

Ward did not reject the theory that the state acquired ownership of all land below the high-water mark of its navigable waters subject to the public rights of navigation and fishery, and that any state disposition of the lands must not impair public rights. Rather, it held that the state may dispose of the lands to "advance and promote the interests of navigation,"133 and that lands under navigable waters may be reclaimed when usable for other purposes and when reclamation would not prejudice the public navigation right. The court found that the salt marshes of the state were not suitable for navigation or fishing and thus could be treated as any other state-owned dry lands. ${ }^{134}$

At this time the state was already heavily engaged in the sale of its tidelands and swamplands. ${ }^{135}$ In Taylor $v$. Underhill ${ }^{136}$ the court held that a purchaser of land, part of which was the bed of a navigable river, under the swamp-and-overflowed-lands acts ${ }^{137}$ could not utilize

129. See, e.g., Eldridge v. Cowell, 4 Cal. 80, 87 (1854):

[California] holds the complete sovereignty over her navigable bays and rivers, and although her ownership is, by the law of nations, and the common and civil law, attributed to her for the purpose of preserving the public easement, or right of navigation, there is nothing to prevent the exercise of her power in certain cases to destroy the easement, in order to subserve the general good, which, when done, subjects the land to private proprietorship.

Here the court seems to be foreshadowing almost precisely the discussion in Illinois Cent. R.R. v. Illinois, 146 U.S. 387, 452-55 (1892).

130. Although the Eldridge language, taken literally, would permit wide latitude to the state im ending the public rights, the later cases limit this exception to land unsuited for navigation and land alienated for the improvement of navigation. See Ward v. Mulford, 32 Cal. 365, 372-73 (1867).

131. 32 Cal. 365 (1867).

132. Id. at $372-73$.

133. Id. at 372. For further discussion of this exception to the public rights, see notes 142-90 infra and accompanying text.

134. 32 Cal. at 372-73.

135. See note 124 supra.

136. 40 Cal. 471 (1871).

137. The statute involved was the Act of March 28, 1868, ch. 415, [1868] Cal. 
the land to interfere with navigation where the land was incapable of reclamation for agricultural purposes. ${ }^{138}$ Ward and Taylor thus indicated that, although lands unsuitable for navigation could be reclaimed, the right to do so depended upon the physical state of the land-not whether it had been sold by the state.

The Ward-Taylor exception to public rights in navigable water lias very limited application today. ${ }^{138}$ The exception was created when navigation purposes and navigable water both had a limited application. The expansion of "trust purposes" to include recreation uses means that as a practical matter any navigable water, which includes even mudflats covered only at high tide, is useful for some trust purpose. $^{140}$ Since this exception applies only to lands truly incapable of recreational uses, its remaining vitality depends upon the extent to which such lands have already been sold and filled. ${ }^{141}$ Therefore, the most important limitation on the scope of the Wilbour doctrine depends upon the extent to which the state can declare property free of the public trust and convey it to private persons regardless of its physical nature.

\section{B. State Sale: The Intention of the Legislature}

At the same time the Ward-Taylor test was being formulated, a

Stat. 507, which was titled "An Act to provide for the management and sale of the lands belonging to the State." It was a general act which provided, "The swamp and overflowed, salt marsh and tide lands belonging to the State shall be sold at the rate of one dollar per acre. . . ." Id. $\S 28$.

138. $40 \mathrm{Cal}$. at 473.

139. A private owner cannot unilaterally cut off his land from navigable water and then fill it, claiming he falls within the Ward-Taylor exception. Such action is a public nuisance [CAL. Crv. Cope $\$ 3479$ (West 1954)] and may be abated. CAI. Crv. CODE $\$ 3491$ (West 1954). Cf. Carpenter v. City of Santa Monica, 63 Cal. App. 2d 772, 147 P.2d 964 (1st Dist. 1944) (an owner of beach land does not gain title to or have any rights in land previously below the low-water mark that was created by artificial means).

140. See Forestier v. Johnson, 164 Cal. 24, 28-29, 127 P. 156, 158 (1912).

141. In San Francisco Bay, for example, 75 miles of marshland remain, less than one-quarter of the original extent. BCDC Supplement 61. However, major areas that could be considered "unsuited for navigation" and subject to fill exist elsewhere in the state. See, e.g., S.F. Chronicle, Nov. 30, 1970, at 5, col. 1 (discussing Tomales Bay).

Since Forestier v. Johnson, 164 Cal. 24, 127 P. 156 (1912), which held that mudflats uncovered at low tide are subject to the public easement, this exception seems limited to waters that are physically cut off from navigable streams, lakes, or the ocean. Cf. Bolsa Land Co. v. Burdick, 151 Cal. 254, 90 P. 532 (1907).

The extent of this exception in fact may be even more limited. Pcople v. Russ, 132 Cal. 102, 64 P. 111 (1901), holds that an owner of land on which there is no navigable water may not act so as to impair the navigation of any navigable waterway. Id. at 106, 64 P. at 112 . Thus, the owner of land over which a tributary flows to a navigable river cannot dain the tributary and reclain his land if such action would adversely affect navigation on the navigable river. Id. 
separate line of decisions held that the state could sell and authorize the filling of land pursuant to a plan to improve navigation. ${ }^{142}$ To implement these programs, the state passed a series of acts, the most significant of which authorized the setting of harbor lines for San Francisco and further authorized the sale of land within the lines without respect to its physical condition. ${ }^{143}$ By 1879 so much land in and along bays and coasts had been sold ${ }^{144}$ that the new constitution passed that year contained a provision reaffirming the common law public navigation rights in state navigable waters. ${ }^{145}$ Continuing abuses led in 1909 to a halt of all state sales of tidelands to private persons, ${ }^{146}$ although the state continued to convey these lands to municipalities. ${ }^{147}$ These developments created much confusion over ownership of and public rights in tidelands that had been sold. In three major decisions written by Justice Shaw, the California supreme court attempted to clarify the existing law.

The first of these cases ${ }^{148}$ involved members of the public who claimed the right to use the water above plaintiff's land when covered at high tide to hunt and fish from small boats; plaintiff's ownership of the land was not disputed. ${ }^{140}$ The only question was whether the statutes under which the state sold the property ${ }^{150}$ also destroyed or va-

142. See San Francisco v. Straut, 84 Cal. 124, 24 P. 814 (1890); People v. Williams, 64 Cal. 498, 2 P. 393 (1884); Knight v. Roche, 56 Cal. 15 (1880); Hyman v. Read, 13 Cal. 444 (1859); Eldridge v. Cowell, 4 Cal. 80 (1854). These cases are the progeny of the Eldridge decision and deal with the special acts relating to San Francisco. See note 128 infra. These decisions also establish the principle that establishment of a larbor line alone does not deprive the state of the power to regulate navigation within that line. People v. Williams, 64 Cal. 498, 499 (1884).

143. Act of March 26, 1851, ch. 41, [1851] Cal. Stat. 307. This act established a "permanent" waterfront for San Francisco. Id. \$ 4. It was the source of title at issue in Eldridge v. Cowell, 4 Cal. 80 (1854). A later act also relating to the San Francisco waterfront [Act of March 30, 1868, ch. 543, [1868] Cal. Stat. 716] became the center of controversy in Knudson v. Kearney, 171 Cal. 250, 152 P. 541 (1915), and thus formed the basis for the improvement-of-navigation exception to public rights. See notes 165-69 infra and accompanying text.

144. BCDC Supplement 433.

145. CAL. CoNST. art. XV, $\S \S 2,3$. See note 122 supra.

146. Ch. 444, § 1, [1909] Cal. Stat. 774 (Political Code $\$ 3443 a$ ) (now CaL. PuB. RES. CODE $\$ 7991$ (West 1956).

147. See M. Scotr, supra note 6, at 11-20, 117-25. Some representative grants are found at ch. 347, [1913] Cal. Stat. 705 (Berkeley); ch. 1336, [1959] Cal. Stat. 3607 (Richmond); cl. 1028, [1955] Cal. Stat. 1936 (Oakland).

148. Forestier v. Johnson, 164 Cal. 24, 127 P. 156 (1912).

149. Id. at $27,29,127 \mathrm{P}$. at $157,158$.

150. Political Code sections 3440 to $34931 \frac{1}{2}$ were the authority under which the land was sold. Id. at $31,127 \mathrm{P}$. at 159 . The court concluded that those sections were not materially different from the Act of March 28, 1868 [cl. 415, [1868] Cal. Stat. 507], and that this act in turn was a revision of previous laws providing basically for the sale of swamp and overflowed lands. Id. at 32-33, 127 P. at 159-60. See notes 124, 137 supra. The Act of March 28, 1868, set up a state land office to 
cated "the dedication of the water to the public uses of navigation and fishery" and vested "in the grantee the right to prevent the public use and convert both land and water to his own private use and possession." 151 The court held that the sale of tidelands does not destroy any public rights in thein, unless the statute that authorized the sale was proinulgated for "the protection or management of navigable waters, or for the regulation of navigation." "162 The statute under which plaintiff acquired title evinced no such legislative intent; ${ }^{163}$ therefore, the public right of navigation in navigable water extending over any tideland granted under the statute was not destroyed and any purchaser took subject to such rights. ${ }^{154}$ In so holding, the court brought itself within the exception in Illinois Central Railroad v. Illinois, ${ }^{165}$ allowing the state to make grants in the interest of commerce and navigation. ${ }^{150}$

The next case, People v. California Fish Co., ${ }^{167}$ examined whether the state may validly sell any land under navigable waters that was not

manage, sell, and, where appropriate, reclaim lands belonging to the state. Ch. 415 , $\S \S 1,28,30$, [1868] Cal. Stat. 514, 530.

151. 164 Cal. at $31,127 \mathrm{P}$. at 159.

152. Id. at $33,127 \mathrm{P}$. at 160 . The court distinguished the cases holding that the state may destroy the public easement $m$ the interests of navigation:

[They were] all cases involving dispositions of lands under statutes adjusting, or authorizing the adjustment of, harbor lines and providing for the sale of lands covered by navigable waters but too far landward of the seawall to be of any use in connection with navigation, statutes which plainly manifested an intent to deal with and terminate the public easement over such lands.

Id. at 32, $127 \mathrm{P}$. at 159 . For a discussion of these cases and statutes, see notes 142-43 supra. This reasoning requires both a specific statute dealing with navigation and ending the public rights and land incapable of use for navigation purposes, although previously the court noted the Illinois Central exception, which required only that the lands be sold in the interest of improving navigation. See note 156 infra. The court may have been misled by early statements asserting that reclamation would probably advance navigation. E.g., Eldridge v. Cowell, 4 Cal. 80, 87 (1854). See note 130 supra.

153. The court discussed the relevant statutes [see note 150 supra]:

No provision is made for the consideration of the subject of navigation or for a decision of the question whether any tide lands are or are not required therefor, or whether the public right of navigation over any given parcel of soil may be discontinued and the dedication of the soil to the public use revoked or vacated without detriment to the general welfare. The scheme is manifestly designed, not as an exercise of the sovereign power of doninion over these lands for the preservation and protection of the right of navigation, or of the duty of the state to promote, control, and regulate it, but as a plan to dispose of the soil of the tide lands in such a manner that the grantee shall take it for reclamation and cultivation subject to the public rights wherever they may exist over such lands.

$164 \mathrm{Cal}$. at 33-34, $127 \mathrm{P}$. at 160.

154. Id. at $34,127 \mathrm{P}$. at 160 .

155. 146 U.S. 387 (1892).

156. Id. at 452. The Forestier court quotes extensively from Illinois Central. 164 Cal. at 30,127 P. at $158-59$.

157. 166 Cal. 576, 138 P. 79 (1913). 
suitable for agriculture or reclamation. ${ }^{158}$ After restating the Ward exception that the state can absolutely dispose of public trust lands to promote navigation, ${ }^{159}$ the court then held that the new constitutional provision made sales of tidelands consummated after its adoption subject to the public rights of navigation, giving the grantee title only to the soil. ${ }^{160}$ In this fashion the court constructed a compromise, protecting public navigation rights while avoiding an excessively harsh rule that would invalidate all sales of nonreclaimable tidelands, by concluding that the purchaser of land under these statutes does receive title but subject to public navigation rights. ${ }^{161}$

Despite an extensive discussion of the circumstances under which the state can dispose of land under navigable water in the interests of navigation, ${ }^{162}$ it was not clear from the opinion what conditions would terminate the public trust. Some language indicated that a state grant to a private party would not terminate the public trust unless the land in question was physically cut off from navigation in the course of
158. Id. at $583-84,138 \mathrm{P}$. at 82 .
159. It is ... settled that in the administration of this trust when the plan or system of improvement or development adopted by the state for the promotion of navigation and commerce cuts off a part of these tidelands or submerged lands from the public channels, so that they are no longer useful for navigation, the state may thereupon sell and dispose of such excluded lands into private ownership or private uses, thereby destroying the public easement in such portion of the lands and giving them over to the grantee, free from public control and use.

$I d$. at $585,138 \mathrm{P}$. at $82-83$. This is a neat way of avoiding Forestier's dual requirement of land incapable of use for navigation and sale under a statute to aid navigation. See note 152 supra. The public rights are extinguished only when the state, in the interests of navigation, makes land unsuitable for such use. This version of the exception is very close to the modern statement. See City of Long Beach v. Mansell, 3 Cal. 3d 462, 482, 476 P.2d 423, 437, 91 Cal. Rptr. 23, 37 (1970).

160. $166 \mathrm{Cal}$. at $587-88,138 \mathrm{P}$. at 83-84. The court relied in part on Forestier v. Johnson, 164 Cal. at $34-35,127$ P. at 160 . Although Forestier claimed the result would be the same before and after passage of the new constitution [id. at 34, $127 \mathrm{P}$. at 160; see note 145 supra and accompanying text], the land involved there was not sold until 1906, after adoption of the constitution. Id. at 27-28, $127 \mathrm{P}$. at 157. In California Fish the court first decided that the lands in question, all sold after 1879, did come under the constitutionally imposed public easement. $166 \mathrm{Cal}$. at 588-89, $138 \mathrm{P}$. at 84. Then it entered into a long discussion, apparently unnecessary for its holding, in order to show that the "same conelusion follows from a consideration of the provisions of the Political Code, apart from the effect of the constitution thereon." Id. at $589,138 \mathrm{P}$. at 84 . This discussion is found $i d$. at $589-96,138 \mathrm{P}$. at 84-87. In the course of its discussion, the court pointed out that the statutes under which tidelands were sold were primarily to provide for reclamation of swamp and overflowed lands, and that tidelands were included only because some had mistakenly been sold as swamp land. Id. at 591-92, $138 \mathrm{P}$. at 84-85. See note 124 supra. Although dictum, this conclusion is vital to claims that land sold prior to 1879 is subject to public navigation rights.

161. 166 Cal. at 596,138 P. at 87.

162. Id. at $585-96,138 \mathrm{P}$. at $82-87$. 
activity aiding or improving navigation, ${ }^{103}$ thus apparently requiring a judicial finding of fact. Other language, however, indicated that the legislature could terminate the public trust by enacting a statute that authorized the sale of public trust land in the aid of navigation, ${ }^{164}$ thus creating absolute private ownership at the time of the sale.

The third of these cases, Knudson $v$. Kearney, ${ }^{100}$ settled this issue in favor of the latter position. The statute in question ${ }^{106}$ autlorized a board of tideland commissioners to take possession of the marshlands and tidelands within the established waterfront of the city and county of San Francisco, survey thein into lots, streets, and alleys, and sell them. ${ }^{167}$ Since the statute was enacted to aid navigation and explicitly provided that tidelands considered unnecessary for navigation should be sold, ${ }^{168}$ the court held that the sales were outright and not subject to the public rights. ${ }^{100}$

163. If, in so adapting the tidelands for this use [navigation], it is found necessary or advisable, in aid of the use, to cut off portions of it from access to navigable water, so that they become unavailable for navigation, the state has power to exclude such portions from the public use and, to that extent, revoke the original dedication.

Id. at $597,138 \mathrm{P}$. at 88.

164. When the state, in the exercise of its discretion as trustee, has decided that portions of the tide land should be thus excluded from navigation and sold to private use, its determination is conclusive upon the courts; but statutes purporting to authorize an abandonment of such public use will be carefully scanned to ascertain whether or not such was the legislative intention, and that intent inust be clearly expressed or necessarily implied. It Id. will not be implied if any other inference is reasonably possible.

Despite the apparent resolution of the ambiguity presented by the language of California Fish [see notes 165-69 infra and accompanying text], modern statements of this exception to the public rights retam similarly ambiguous language:

[T] The state in its proper administration of the trust may find it necessary or advisable to cut off certain tidelands froin water access and render them useless for trust purposes. In such a case the state through the Legislature may find and determine that such lands are no longer useful for trust purposes and free thein from the trust.

City of Long Beach v. Mansell, 3 Cal. 3d 462, 482, 476 P.2d 423, 437, 91 Cal. Rptr. 23, 37 (1970).

165. 171 Cal. 250, 152 P. 541 (1915).

166. Act of March 30, 1868, ch. 543, [1868] Cal. Stat. 716.

167. Id. $\S \S 1,4-5$. Sales were made by deed. Id. $\S 7$. The more general statutes imvolved in California Fish made sales by patent. Act of March 28, 1868, ch. 415, $\S 5$, [1868] Cal. Stat. 508. For Knudson's discussion of the statute, see $171 \mathrm{Cal}$. at $251-52,152$ P. at 541.

168. Act of March 30, 1868, ch. 543, §§ 4-5, [1868] Cal. Stat. 717, 719.

169. $171 \mathrm{Cal}$. at $253,152 \mathrm{P}$. at 542 . Unfortunately, the fine distinctions drawn by the court in legislative purpose and intention still raise difficulties. Recently the California court of appeals in Marks v. Whitney, 80 Cal. Rptr. 606 (1969), held that land sold under the statutes involved in Forestier and California Fish [Act of March 28, 1868, ch. 415, [1868] Cal. Stat. 507 (general statute providing for state sale of swamp and overflowed land); see note 150 supra] was conveyed free of any public rights [80 Cal. Rptr. at 607-09], erroneously relying on cases dealing with the statutes in 
This exception to the rule of predominant public rights-that the legislature can statutorily terminate the public rights-has received recognition even in states that give the broadest interpretation to the public interest. ${ }^{170}$ Since the basic theory is that the state is the guardian or trustee of the public rights, ${ }^{171}$ its power to terminate the public easement must be limited by its fiduciary capacity, ${ }^{172}$ and Illinois Central does prohibit large-scale giveaways. ${ }^{173}$ However, courts have encountered greater difficulty in formulating more precise restrictions. ${ }^{174}$

The state's fiduciary standing with regard to its public trust lands implies that state termination of public navigation rights would be justified only if it promotes a purpose equally in the public interest. ${ }^{175}$ Termination of public rights in favor of a purely private gain could not be justified. ${ }^{178}$ Nevertheless, the statutes in Knudson reveal little if any public purpose beyond raising revenue for the state. While the original law does provide for establisinent of a harbor line in the city of San Francisco, allowing deeper draft vessels to use the port, ${ }^{177}$ its subse-

Knudson. Id. [The statutes in Knudson were Act of March 30, 1868, ch. 543, [1868] Cal. Stat. 716, and Act of April 1, 1870, ch. 388, [1870] Cal. Stat. 541 (providing for setting the San Francisco harbor line and selling land within it); see notes 166-68 supra and accompanying text]. On rehearing, however, the court reversed itself and limited its holding to the rights between the two private parties. Marks v. Whitney, $90 \mathrm{Cal}$. Rptr. 220, 223 (1st Dist. 1970). The property involved is tideland situated on Tomales Bay. Id. at 220. See note 141 supra. See Marks v. Whitney, S.F. 22566 (Cal. Sup. Ct., Dec. 9, 1971) (holding the land subject to the public trust).

170. Perhaps the strongest public trust state, Wisconsin, permits the establishment of bulkhead lines and allows fills and otlier structures both within and without the lines. Wrs. Stat. ANN. $\$$ 30.11-.13 (1964, Supp. 1970). See note 36 supra. See Hixon v. Public Serv. Coinın'n, 32 Wis. 2d 608, 146 N.W.2d 577 (1966); Town of Ashwaubenon v. Public Serv. Comm'n, 22 Wis. 2d 38, 125 N.W.2d 647 (1963); City of Madison v. State, 1 Wis. $2 d$ 252, 83 N.W.2d 674 (1957); State v. Public Serv. Comm'n, 275 Wis. 112,81 N.W.2d 71 (1957). The Wisconsin doctrine, while not allowing alienation of lands under navigable water irrevocably into private ownership, does allow the sacrifice of public navigation rights when in the public interest. Id. at 117-20, 81 N.W.2d at 73-74.

171. Illinois Cent. R.R. v. Illinois, 146 U.S. 387, 452 (1892); People v. California Fish Co., 166 Cal. 576, 584, 138 P. 79, 82 (1913); Ward v. Mulford, 32 Cal. 365, 372 (1867); Muench v. Public Serv. Comm'n, 261 Wis. 492, 499, 53 N.W.2d 514, 517 (1952).

172. See note 44 supra and accompanying text.

173. 146 U.S. at 452-53.

174. See notes 162-64 supra and accompanying text.

175. Legislative grants explicitly authorizing filling have generally been limited to a specific purpose equally in the public interest. See, e.g., Atwood v. Hammond, 4 Cal. 2d 31, 48 P.2d 20 (1935) (civic center); City of Madison v. State, 1 Wis. 2d 252, 83 N.W.2d 674 (1957) (auditorium and civic center); State v. Public Serv. Comm'n, 275 Wis. 112, 81 N.W.2d 71 (1957) (park development).

176. State v. Public Serv. Comm'n, 275 Wis. 112, 81 N.W.2d 71, 74 (1957); cf. City of Long Beach v. Mansell, 3 Cal. 3d 462, 482, 476 P.2d 423, 437, 91 Cal. Rptr. 23, 37 (1970).

177. Act of March 30, 1868, ch. 543, $\$ 4,[1868]$ Cal. Stat. 717. 
quent extension to lands within five miles of the city ${ }^{178}$ was a disposal of public land that preserved only minimal navigation access. ${ }^{170}$

State action of this sort with regard to the public trust fails to meet even the minimum standard of Illinois Central ${ }^{80}$ and would liave been invalidated had the Knudson court carefully evaluated the facts before it and followed the language of California Fish. ${ }^{181}$ Nevertheless, Knudson did rest on statutes expressly purporting to aid navigation, and future courts inay look more closely at the factual realities they face. Little can now be done in favor of public riglits in the Knudson lands, because, at least where the land lias already been filled, abatement actions will probably be barred by estoppel. ${ }^{182}$ However, future fills in San Francisco Bay are now regulated by the San Francisco Bay Conservation and Development Commission (BCDC), ${ }^{183}$ thus guaranteeing that, at least in San Francisco Bay, decisions will fully consider the public interest. ${ }^{184}$ Furtliermore, modern lioldings of the California supreme court $^{185}$ indicate that sucli wholesale dispositions of tidelands would violate explicit state constitutional directives. ${ }^{\mathbf{1 8 6}}$

Impairment of public navigation rights by the legislature is thus subject to two forms of limitation. First, major abdication of the state's trust responsibility violates the rule of Illinois Central. ${ }^{187}$ Second, any legislative program of state land sale that purports to terminate the public rights must be for a legitimate public purpose. ${ }^{188}$ Major land dis-

178. Act of April 1, 1870, ch. 388, § 1, [1870] Cal. Stat. 541.

179. The commissioners were authorized to sell all the land out to the nine-foot level at low tide except for two canals 600 feet wide. Act of April 1, 1868, ch. 388, $\S 2$, [1870] Cal. Stat. 541. Although some navigation capability was thus preserved, there is no pretext of improvement. Apparently the act was extended because all the land available under the earlier version [Act of March 30, 1868, ch. 543, [1868] Cal. Stat. 716] had been sold and the state was eager to make more sales. M. Scort, supra note 6 , at $5-7$.

180. That is, that large-scale alienation of state trust lands without a counterveiling public purpose is prohibited. 146 U.S. at 452-53. See text accompanying notes 44-45 supra.

181. See note 164 supra.

182. See notes 196-210 infra and accompanying text.

183. CAL. Gov'T CODE $\$ \S 66600-61$ (West Supp. 1971).

184. CaL. Gov't CODE $\S 66632$ (West Supp. 1971).

185. Cf. City of Long Beach v. Mansell, 3 Cal. 3d 462, 482-86, 476 P.2d 423, 437-40, 91 Cal. Rptr. 23, 37-40 (1970); Newcomb v. City of Newport Beach, 7 Cal. 2d 393, 398-402, 60 P.2d 825, 827-30 (1936).

186. See note 198 infra.

187. 146 U.S. $387,452-53$ (1892).

188. City of Long Beach v. Mansell, 3 Cal. 3d 462, 482, 476 P.2d 423, 437, 91 Cal. Rptr. 23, 37 (1970); Colberg, Inc. v. State ex rel. Dep't of Pub. Works, 67 Cal. 2d 408, 417, 432 P.2d 3, 9, 62 Cal. Rptr. 401, 407 (1967), cert. denied, 390 U.S. 949 (1968); People v. California Fish Co., 166 Cal. 576, 585, 138 P. 79, 82-83 (1913). 
posal schemes must be related to navigation improvement, ${ }^{189}$ and sinaller actions should satisfy the minimal standard of having a public purpose. ${ }^{190}$

Where most if not all state lands capable of private uses have been sold pursuant to some state statute, the legislative intent test is the most important criterion in determining whether land remains subject to public riglits. However, the Ward-Taylor test that lands wholly unsuited for trust purposes are not subject to public navigation rights ${ }^{101}$ is probably the most important exception to the assertion of public rights and, consequently, to the Wilbour doctrine in states where extensive sale of land under navigable water has not occurred. Since California belongs in the former category, the suitability test becomes crucial there only if the land has not been sold or if it has been sold under a statute that does not qualify under the aid-to-navigation strict-construction-of-intent test.

It is sometimes argued that the land's physical condition is the only valid test to determine whether property is subject to public navigation rights. ${ }^{192}$ Such arguments purport to rely on cases like Bohn v. Albertson, ${ }^{193}$ where the public was permitted the use of navigable water covering what was clearly privately owned land that the state had never held. But this reliance is misplaced. While Bohn accepted the notion that the public nay use any navigable waters that exist, ${ }^{104}$ its postulate that owners not responsible for the submersion of their lands can terminate all public use by reclaiming the land ${ }^{195}$ crucially limited it. Similarly, land sold into absolute private ownership by the state may be used by the public until the owner decides to do sometling else with it. Therefore, public rights of the type recognized in Bohn cannot be the sole basis for holding that filling constitutes an obstruction to navigation in violation of public rights. Nor can they be used to support the theory that the physical condition of the land is the only test for determining the existence of public rights. In order for the Wilbour doctrine to come into play, public rights must predominate over the own-

189. Knudson v. Kearney, 171 Cal. 250, 152 P. 541 (1915); Alameda Conservation Ass'n v. City of Alameda, 264 Cal. App. 2d 284, 70 Cal. Rptr. 264 (1st Dist. 1968), cert. denied, 394 U.S. 906 (1969).

190. The determination of a public purpose may be subject to review under a reasonableness test. Cf. Hixon v. Public Serv. Comm'n, 32 Wis. 2d 608, 629, 146 N.W.2d 577, 587 (1966).

191. Such are lands cut off from any access to navigable water. Cf. Bolsa Land Co. v. Burdick, 151 Cal. 254, 90 P. 532 (1907). See note 141 supra.

192. See Comment, San Francisco Bay: Regional Regulation for its Protection and Development, 55 CALIF. L. REv. 728, 777 (1967). This whole area of the law is discussed there to determine its effect on the powers asserted by the BCDC. Id. at $772-77$.

193. 107 Cal. App. 2d 738, 238 P.2d 128 (1st Dist. 1951).

194. Id. at $749,238 \mathrm{P} .2 \mathrm{~d}$ at 135 .

195. Id. 
er's ability to use the land as he pleases. Whether the owner has this ability in California depends upon the intention of the legislature as expressed in the statute that authorized the original sale.

\section{Estoppel}

The first two major limitations on the scope of the Wilbour holding's applicability involve state action in selling lands under navigable waters. A third limitation also exists that can successfully abrogate public rights even without state action and without any sale. In City of Long Beach v. Mansell, ${ }^{196}$ the California supreme court considered the legal consequences of filling and developing former tideland that had never been sold by the state. ${ }^{197}$ The court agreed that the lands involved were tidelands as of the passage of the constitutional restriction prohibiting their sale adopted in $1879^{198}$ and did not come under a judicially created exception to that provision. ${ }^{109}$ However, the

196. 3 Cal. 3d 462, 476 P.2d 423, 91 Cal. Rptr. 23 (1970).

197. The set of circumstances that led to this controversy is extremely complicated. See id. at 467-78, 476 P.2d at 426-34, 91 Cal. Rptr. at 26-34.

198. Id. at 478-79, $476 \mathrm{P.2d}$ at 434-35, $91 \mathrm{Cal}$. Rptr. at 34-35. The constitutional provision involved was CAL. CoNST. art. XV, $\$ 3$ :

All tidelands within two miles of any incorporated city, city and county, or town in this State, and fronting on the water of any harbor, estuary, bay, or inlet used for the purposes of navigation, shall be withheld from grant or sale to private persons, partnerships, or corporations. . . . .

The initial question concerned whether "tidelands" refers to lands seaward of mean high tide at the time of proposed conveyance or at the adoption of the constitution in 1879. $3 \mathrm{Cal}$. $3 \mathrm{~d}$ at $478,476 \mathrm{P} .2 \mathrm{~d}$ at $434,91 \mathrm{Cal}$. Rptr. at 34 . The court concluded that 'the word 'tidelands' as used in article XV, section 3, denotes lands which were seaward of the mean high tide line when the provision was adopted in 1879." Id. at 479,476 P.2d at 435,91 Cal. Rptr. at 35. Thus tidelands filled since 1879 remain incapable of alienation.

199. Id. at 486-87, 476 P.2d at 440-41, 91 Cal. Rptr. at 40-41. The exception comes from Atwood v. Hammond, 4 Cal. 2d 31, 48 P.2d 20 (1935). The Mansell court, in deciding whether various portions of the agreements violated article $X V$, section 3, first held that certain portions were legitimate boundary settlenents:

When the boundary between public trust tidelands and private uplands is uncertain, and the parties, wishing to fix the boundary in order to prevent future questions of ownership, undertake genuine efforts to determine the true bonndary and thereafter agree to a line which fairly represents these efforts, then the subsequent formal "conveyance" in the form of a quitclaim deed by the trustee in furtherance of the boundary agreement does not evidence a "grant or sale" of public tidelands within the meaning of article XV, section 3 , of the state Constitution.

Id. at 480, 476 P.2d at 436, $91 \mathrm{Cal}$. Rptr. at 36, reaffirming Muchenberger v. City of Santa Monica, 206 Cal. 635, 275 P. 803 (1929). The court refused to extend this principle to portions of the agreements that drew boundaries for convenience regardless of the true boundary. $3 \mathrm{Cal}$. $3 \mathrm{~d}$ at 481,476 P.2d at 436-37, 91 Cal. Rptr. at 36-37. It then turned to a consideration of Atwood, and concluded that a limited exception to the prohibition of article $\mathrm{XV}$, section 3, existed:

[When tidelands otherwise subject to the provision] (1) have been found and determined by the Legislature to be valueless for trust purposes and are 
court concluded that the state and city were estopped from asserting any rights, even public trust rights, to the property in question. ${ }^{200}$

The court applied a two-fold analysis, first concluding that the elements of equitable estoppel against the city and state were present. ${ }^{201}$ The court next proceeded to the more difficult issue:

When the state, acting both directly and through its subtrustee the city, conducts itself relative to public trust lands in a manner which would estop it from asserting paramount title if it were a private person, can it be bound by a similar estoppeleven when the effect thereof would be to quiet title to such trust lands in private persons in the face of an express constitutional provision forbidding the alienation of such lands? ${ }^{202}$

The court made its determination by balancing two conflicting principles: avoidance of manifest mjustice and preservation of the public interest. ${ }^{203}$ The court offered no concrete guidelines, however. It rejected the argument that estoppel cannot be apphed where the public entity does not have the legal power to accomphish directly what the estoppel accomplishes indirectly. ${ }^{204}$ Furthermore, the court concluded,

freed from the public trust . . . and (2) liave been or are to be reclaimed pursuant to and $i m$ the course of a highly beneficial public program of harbor development, such lands-if they constitute a relatively small parcel of the total acreage involved-thereupon cease to be "tidelands" withm the meaning of the constitutional provision and are subject to alienation into absolute private ownership.

$3 \mathrm{Cal}$. 3d at 485-86, 476 P.2d at 440, $91 \mathrm{Cal}$. Rptr. at 40 . This is a specialized restatement of the general rule for state transfers into private ownership free of the public trust. Knudson v. Kearney, 171 Cal. 250, 152 P. 541 (1915); People v. California Fish Co., 166 Cal. 576, 597, 138 P. 79, 88 (1913).

200. 3 Cal. 3d at 501, 476 P.2d at 451, 91 Cal. Rptr. at 51.

201. The court first set out the four elements generally required for an application of equitable estoppel:

(1) the party to be estopped must be apprised of the facts; (2) he must intend that his conduct shall be acted upon, or must so act that the party asserting the estoppel had a right to believe it was so intended; (3) the other party must be ignorant of the true state of facts; and (4) he must rely upon the conduct to his injury.

Id. at 489,476 P.2d at 442,91 Cal. Rptr. at 42, quoting Driscoll v. City of Los Angeles, $67 \mathrm{Cal}$. 2d 297, 305, 431 P.2d 245, 250, 61 Cal. Rptr. 661, 666 (1967). The court then decided that in land title questions, the culpability under the second element above must be such that actual or constructive fraud would result were there no estoppel. 3 Cal. 3d at 491, 476 P.2d at 444, 91 Cal. Rptr. at 44. See Biddle Boggs v. Merced Mining Co., 14 Cal. 279, 367-68 (1859), appeal dismissed, 70 U.S. (3 Wall.) 304 (1865). The court had no difficulty concluding that the facts fulfilled the requirement for estoppel in a land title situation. $3 \mathrm{Cal}$. $3 \mathrm{~d}$ at $492-93,476 \mathrm{P} .2 \mathrm{~d}$ at 444-45, 91 Cal. Rptr. at 44-45.

202. 3 Cal. $3 d$ at 493,476 P.2d at 445,91 Cal. Rptr. at 45.

203. Id. at $496-97,476$ P.2d at 448,91 Cal. Rptr. at 48.

204. Id. at 497-99, 476 P.2d at 448-50, 91 Cal. Rptr. at 48-50. See County of San Diego v. California Water \& Tel. Co., 30 Cal. 2d 817, 186 P.2d 124 (1947); Taylor v. Spear, 196 Cal. 709, 717, 238 P. 1038, 1041 (1925). 
the state and city were not utterly without the power to convey title to tidelands. ${ }^{205}$

The court was unwilling to permit the city to ignore its past conduct: ${ }^{206}$ it had never treated the land in question as anything other than private property. ${ }^{207}$ A violation of the public trust by its putative fiduciary, the state, in a sufficiently reprehensible inanner should not result in the termination of the public's rights, although the inference from Mansell that public rights in navigable waters may be lost by the state's failure to assert those rights suggests this anomalous conclusion. However, the decision can be reconciled more easily on practical grounds. The lands were no longer tidelands nor was public use of them likely. The boundary of the tideland area was unclear and appeared not to be capable of exact determination, mdicating public rights could never be adequately reestablished. ${ }^{208}$ Moreover, as the court pointed out, private developinent of the area as a whole resulted in significant public rights and facilities for navigation and recreation. ${ }^{200}$

205. $3 \mathrm{Cal} .3 \mathrm{~d}$ at $498-99,476$ P.2d at 449-50, 91 Cal. Rptr. at 49-50, citing Atwood v. Hammond, 4 Cal. 2d 31, 48 P.2d 20 (1935) and Muchenberger v. City of Santa Monica, 206 Cal. 635, 275 P. 803 (1929). See note 199 supra.

206. 3 Cal. 3d at $472,492,476$ P.2d at 430, 444-45, 91 Cal. Rptr. at 30, 44-45. The court noted that the land was

filled and improved with the knowledge and acquiescence of the state and city and that since the annexation of the area in 1923 the city has exercised full nunicipal jurisdiction over it-granting building permits, approving subdivision maps, constructing and maintaining streets and city services, collecting taxes.

Id. at 487,476 P.2d at $441,91 \mathrm{Cal}$. Rptr. at 41 . The land was filled with governmental approval. Id. at $471,476 \mathrm{P} .2 \mathrm{~d}$ at $430,91 \mathrm{Cal}$. Rptr. at 30 .

207. Id. at 499,476 P.2d at 450,91 Cal. Rptr. at 50.

208. The lands are now a residential area. Id. at 472,476 P.2d at 430,91 Cal. Rptr. at 30. The possibility of a multiplicity of law suits contributed to this last conclusion.

209. Id. at 500, 476 P.2d at 451, 91 Cal. Rptr. at 51. In the area as a whole there is now a major marina and public stadium. Public uses of the area's facilities include sailing, water skiing, power boating, bathing, fishing, and clamming. Ill. at 500 n.34, 476 P.2d at 451 n.34, 91 Cal. Rptr. at 51 n.34.

Although the court viewed the application of estoppel here as a narrow precedent not likely to recur often [id. at 500, $476 \mathrm{P} .2 \mathrm{~d}$ at $451,91 \mathrm{Cal}$. Rptr. at 51], it is certainly not the only area of the state where similar events have occurred. BCDC Supplenient 436. Thus, this further erosion of public rights should not be disregarded.

In Wilbour itself the estoppel question was raised, since other filling had occurred in the area without objection. The trial court relied on estoppel in deciding that the fills need not be removed. 77 Wash. $2 d$ at 312,462 P.2d at 236 . The estoppel was apparently asserted against the Wilbours privately, but since they also brought the action in the naine of the public, it was in this context that the court decided the case. The court decided that there was no counterbalancing gain to the public by applying estoppel against it. In contrast to Mansell, reestablishment of the public rights was easily accomplished in Wilbour, and private development of the area had not resulted in public facilities for recreation and navigation, but rather threatened all public access to the lake. 77 Wash, $2 d$ at $316 n, 13,462$ P.2d at $239 n, 13$. 


\section{CoNCLUSION}

Public navigation riglits liave been long established in the common law, and in the United States they have been accepted and expanded. Courts should have little difficulty in finding that fills in navigable waters do constitute obstructions to navigation subject to abatement. The legal theory is reasonably clear and can have application to all navigable waters-oceans, rivers, lakes; natural and artificial; fluctuating and constant.

The difficulties with and limitations to this concept arise froin the past actions of the states, to which protection and enforcement of the public rights liave been delegated. States have power to terminate the public riglits under proper circumstances and for public purposes. The major problein, however, conies fron state conveyances of major areas of land under navigable water to private parties for nonpublic purposes, which nevertheless apparently terminate the public rights. Only the grossest of these actions are subject to judicial reniedy, and even then estoppel nay bar assertion of the public interest.

Where the state has not acted, the Wilbour doctrine enables the courts to halt all purely private fills. The private owner would then be forced to seek state approval, which would require that allowance be made for the public interest. Where the state has niade wholesale conveyances, legal reinedies may be available if the private owners have not made significant investments in their property. And owners of property that is at least occasionally covered with navigable water should be on notice that public rights are also present, and that longterm natural or artificial changes in lakes and rivers can ripen into permanent public prerogatives. The biggest questions in this area arise where the states have eroded public rights in a piecemeal fashion, and it is here that courts must be most vigilant in examining the imtention of the legislature to determine whether public rights liave been validly terminated.

Forceful judicial action in this area should serve both to protect existing public rights and to force legislative action. The Wilbour court was faced with two alternatives: it could deny the public any rights in the area periodically submerged, or it could curtail the owner's rights so severely that no profitable use of the land was possible. ${ }^{210}$ This indicates the inherent inflexibility of judicial solutions in this area-the public is protected, but the price is stagnation. Moreover, a judicial prohibition on fills in navigable waters cannot substitute for comprehensive controls, since it would restrict only developments that require filling. Although such a prohibition should have greater effect on de-

210. See note 117 supra. 
velopments around lakes and along streams than along the coast, in all three areas its use is essentially a stopgap measure, simply halting development where filling is utilized, but not promoting any positive development.

Alternative legislative solutions exist. In California, a bill is before the legislature that would create a State Coastal Commission and six Regional Commissions with interim permit powers over developments in the coastal zone. ${ }^{211}$ The Commission would operate until the state can prepare a master plan for the coast that coordinates development while preserving the public rights. ${ }^{212}$ Similar arrangements are conceivable that would cover lakes, streams, and other navigable waters. The San Francisco Bay Conservation and Development Commission $^{213}$ lias proven that such arrangements can be successful and can become viable permanent organizations. It is the legislature that has always borne the major responsibility for adjusting public and private rights in the state's navigable waters, and it is there that the responsibility rests now.

Rex Perschbacher

211. S.F. Sunday Examiner \& Chronicle, May 30, 1971, This World, at 25. The coastal zone would extend three miles offshore and about half a mile inland in most areas. $I d$.

212. Id.

213. See note 6 supra. 